معارف ومصادر معلومات زُراع المزارع السمكية بالتوصيات الفنية الخاصة

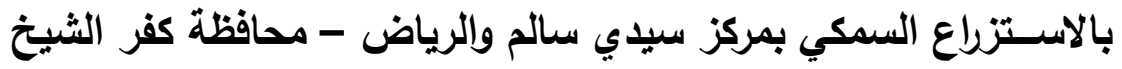

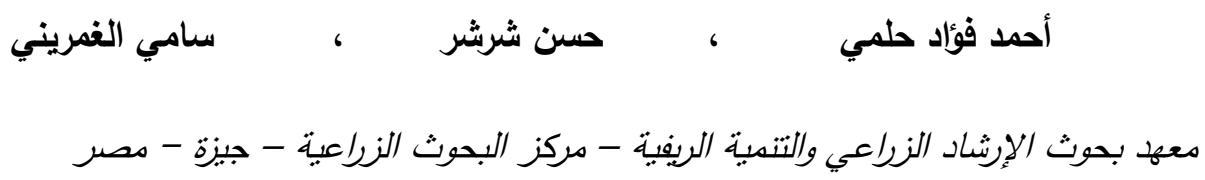
استهدف البحث بصفة اساسية تحديد معـارف زراع المزارع السمكية الخاصـة بالاستزراع

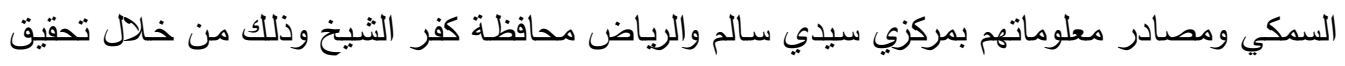

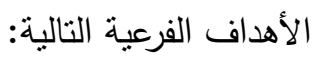
1- التعرف على مستوى المعارف الدكتسبة من مصادر معلومـات الزراع في عمليات الاستزراع

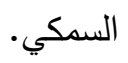
2- تحديد العلاقة الارتباطية بين السمات المميزة للمبحوثين ومعارفهم في عمليات الاستزراع السمكي. 3- تحديد الأهمية النسبية لعمليات الاستزراع السمكي. 4- تحديد الأهيدة النسبية لدصادر المعلومات التي يكتسب منها الدبحوثين معارفهم عن عطليات

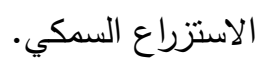

5- تحديد المشاكل التي تواجه المبحوثين وكذا الحلول المناسبة من وجهة نظرهم.

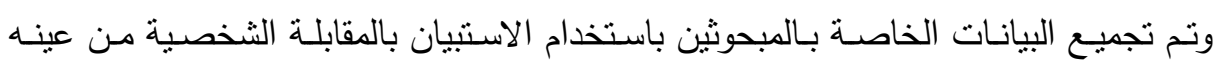

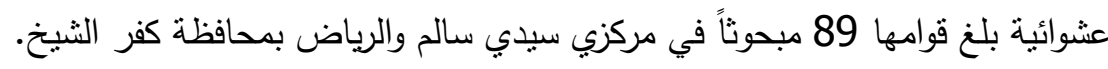

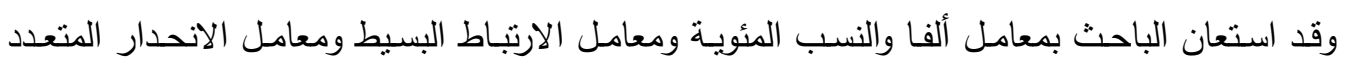
كأساليب إحصائية. وقد أسفرت الاراسة عن النتائج التالية:

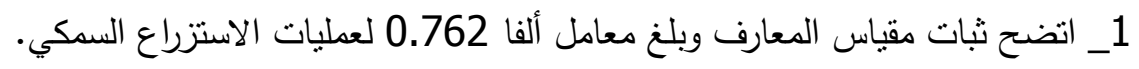

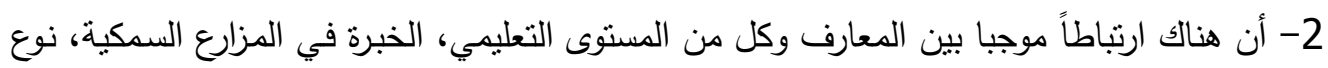

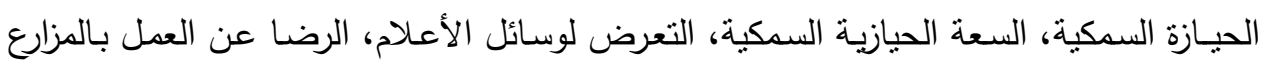

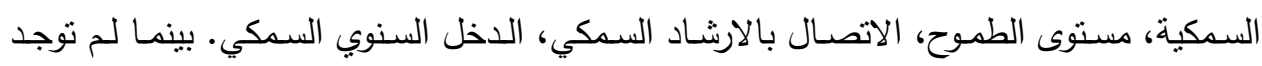
علاقة بين المعارف وكل من متغيري العمر ، المشاركة في الأنشطة الارشادية.

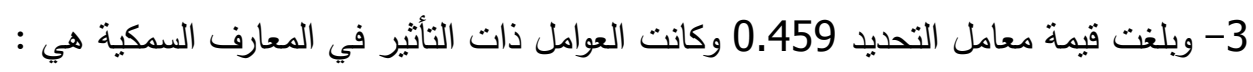

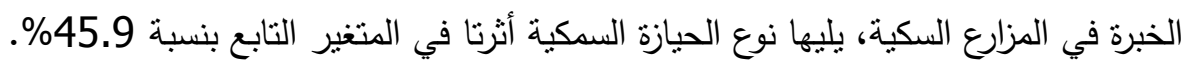

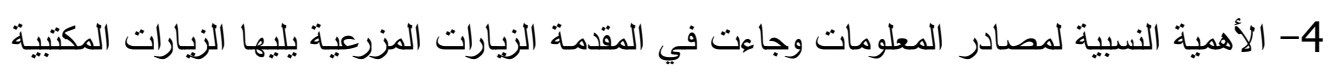

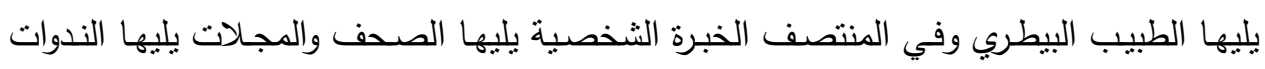
الإرشادية وفي المؤخرة البرامج التليفزيونية و الإيضاحات العملية للبرامج الإذاعية.

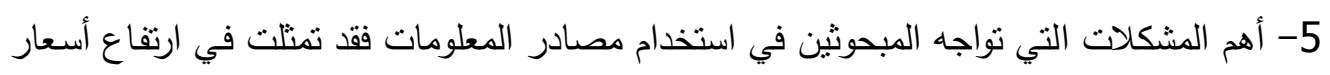

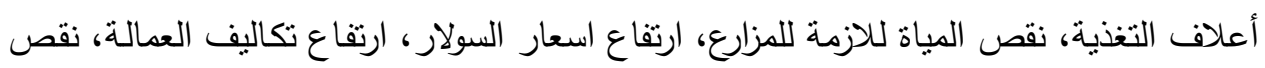


أعداد المرشدين، انخفاض أسعار بيع السمك لتجار الجملة. وقد تمثلت اهم مقترحاتهم لإيجاد حلول لتلك المشكلات في أنخفاض أسعار أعلاف التغذية، توفير المياة للمزارع، انخفاض أسعار السولار ، أنخفاض تكاليف العمالة، زيادة أعداد المرشدين، زيادة أسعار بيع السمك لتجار الجملة.

\section{المقدمة والمشكلة البحثية}

تعد تقنيات الاتصـال أحد أهم المتطلبـات الأساسية لنقل ونشر الأفكار الجديدة، والتقنيات

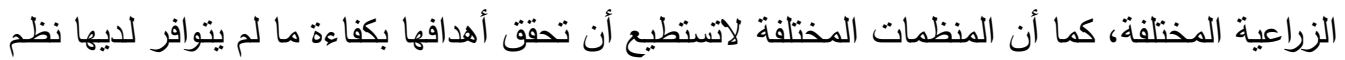

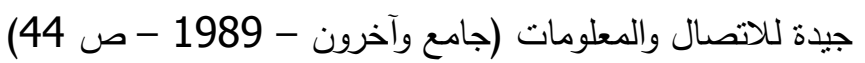
ويعتبر استجابة الزراع لمصـادر المعلومات الزراعيـة عاملا هامـا في تتشكيل وتغيير طريقة تفكيرهم وتحديث سلوكهم الإنتاجي، خاصـة في ظل سياسـات التحرر الاقتصـادي والتحول إلى نظـام

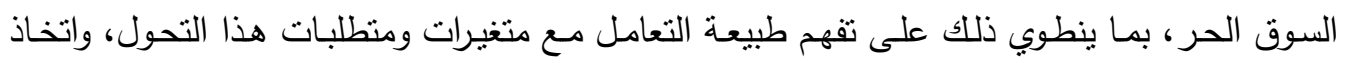

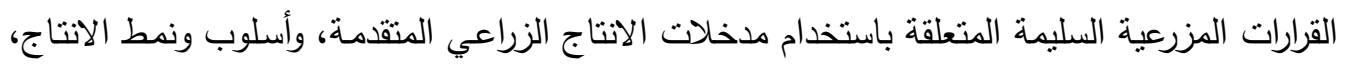

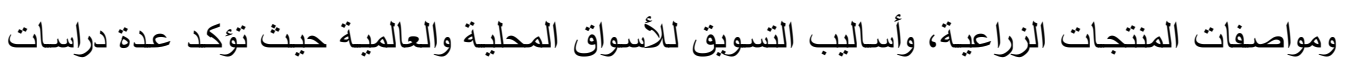
إرشادية على وجود علاقة إيجابية بين مستوى استخدام الزراع لمصادر المعلومات الزراعية واتجاههم نحو التحول إلى آليات السوق الحر وتطبيق التقنيات المنطورة في كافة العمليات الانتاجية والتسويق لرديق

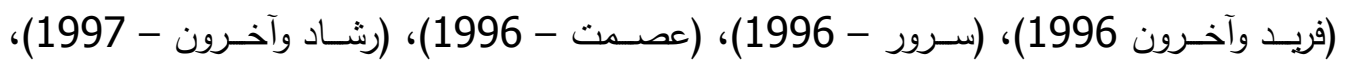

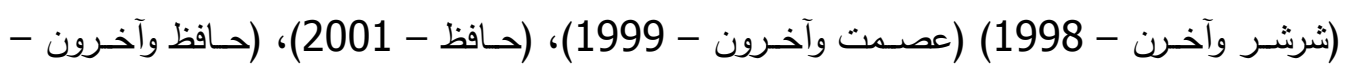
2003)، حلمي وآخرون 2003) (حمي وآخرون - 2007)، (حلمي وآخرون - 2007). ويصنف عبد الظاهر مصادر المعلومات إلى مصادررسمية وتعني أن المسئول عن الاتصسال ويقوم بـه بحكم دوره أو مسئولياته الرسمية كالمرشد الزراعي، ومصـادر غير رسمية وبها ينت القيام

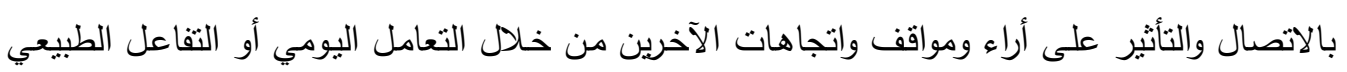

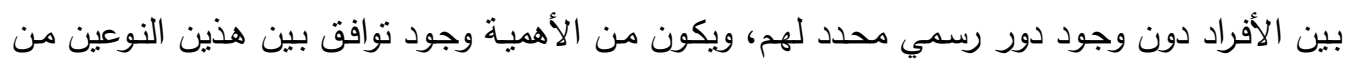

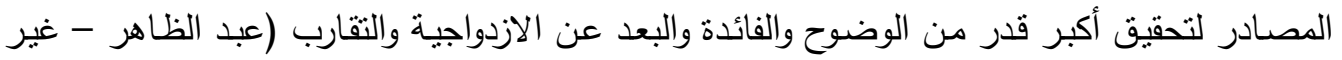

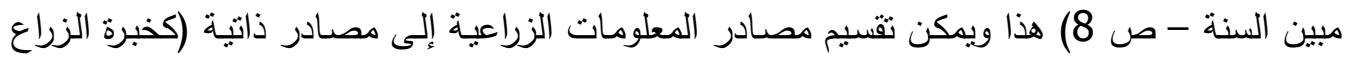

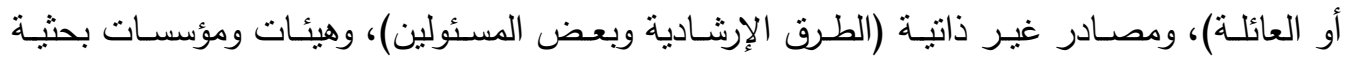

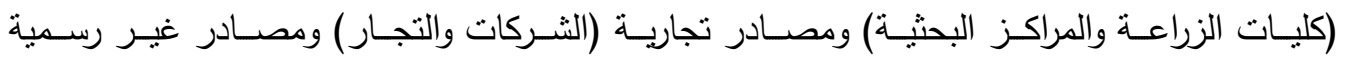
(كالأصدقاء والجيران) ومصادر إرشادية تتموية (كمشاريع تتموية ريفية). (روضان وآخرون - 2001,

ص 8)

ويثـير جـابر وآخـرون (2000 - ص 106) أن مصـادر المعلومـات تتقسـم إلـى مصـادر

تفاعلية (متعددة الوسائط) والمصادر المهنة (الحاسبات الإككترونية، والعمليات الضونئية، وأنثعة الليزر والأقمار الصناعية).

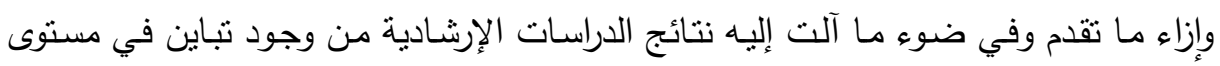

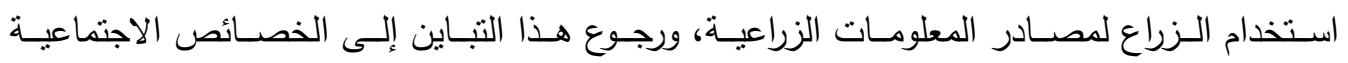

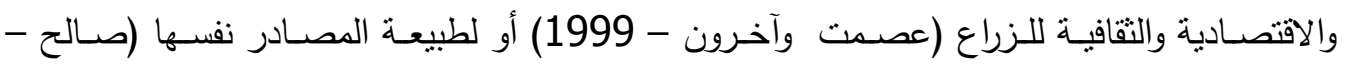




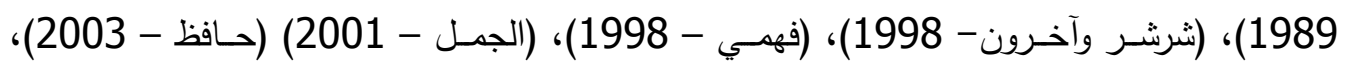

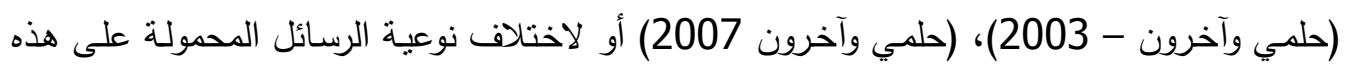

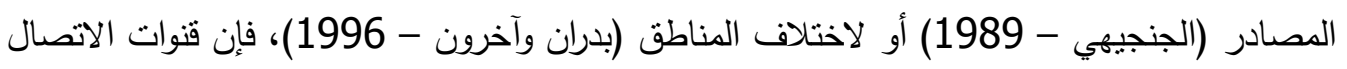

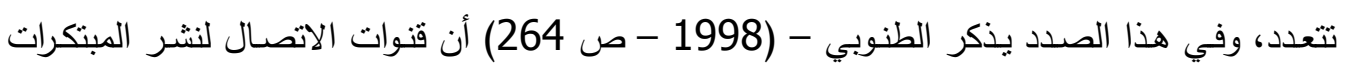

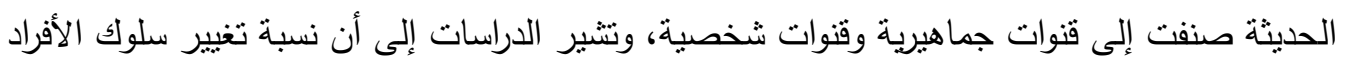

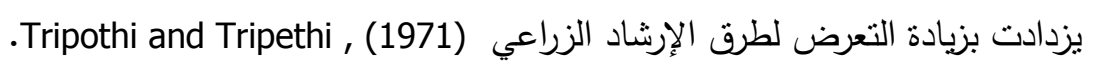

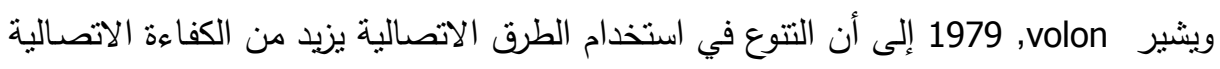

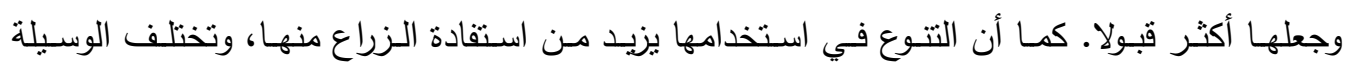

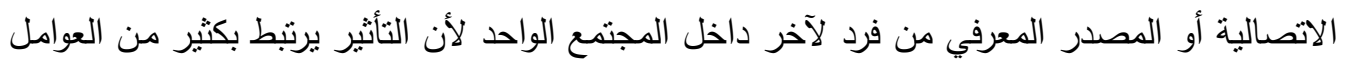

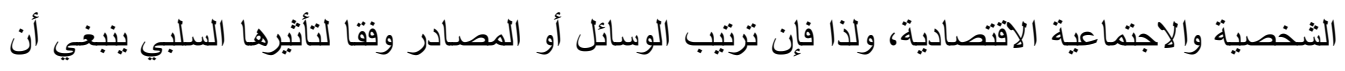

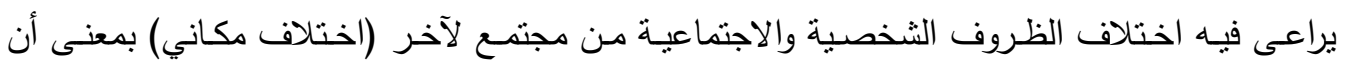

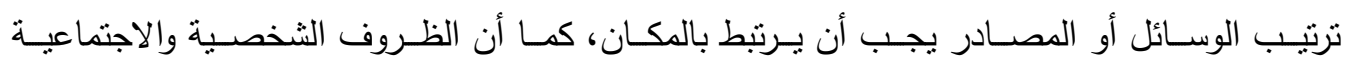

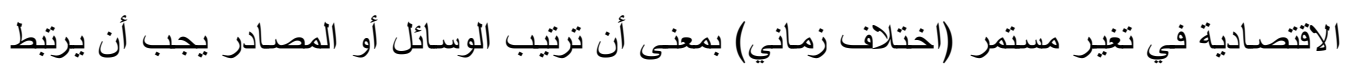

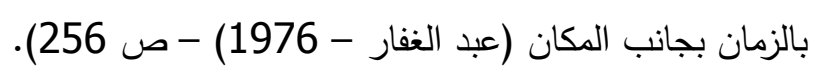

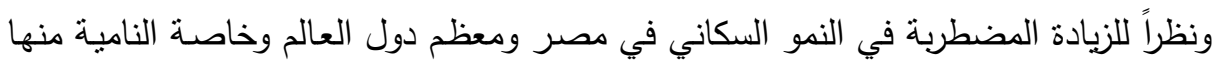

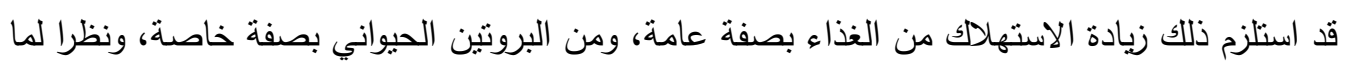

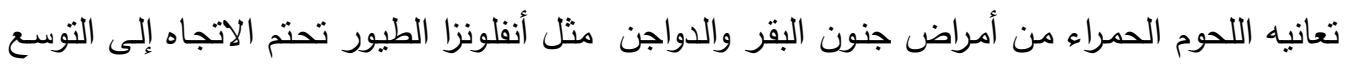

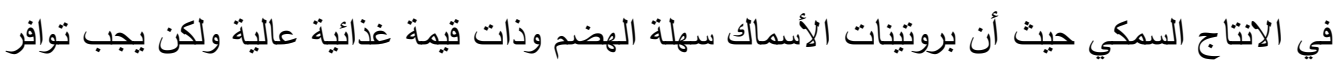

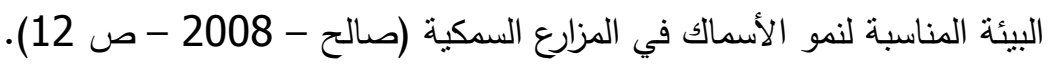

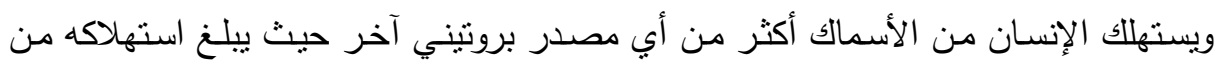

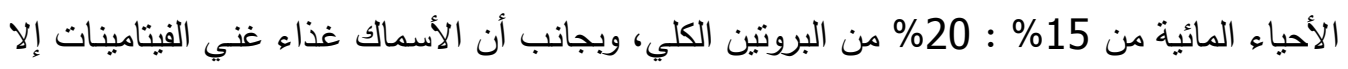

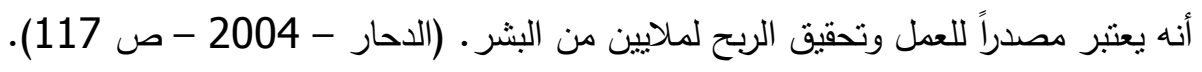

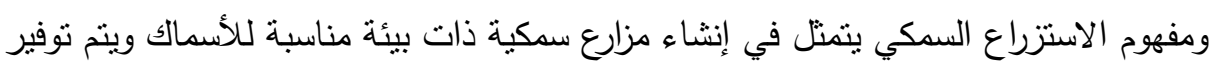

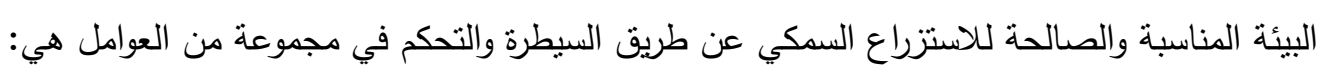
درجة الحرارة- كمية الأكسجين - درجة الملوحة - درجة PH - التخلص من الفضلات الفات والمواد السامة الناتجة من تحلل الغذاء - طرق التغذية - مقاومة الأمراض المختلفة - توفير زريعة جيدة - توفية - توفير

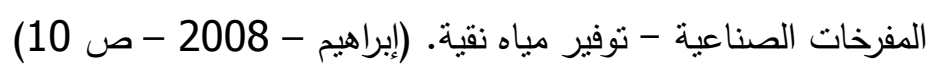

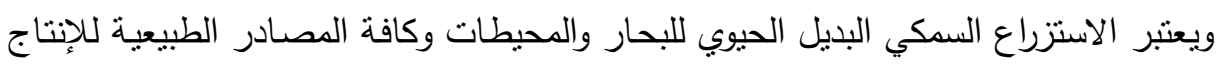

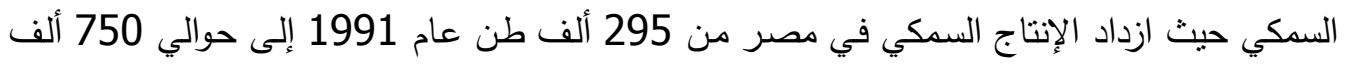

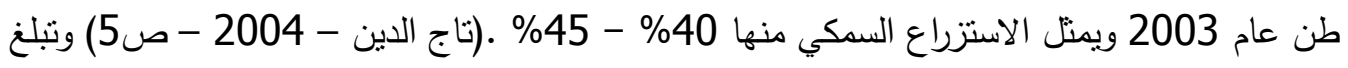

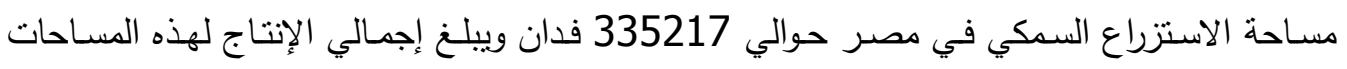
حوالي 456700.524 طن. (الهيئة العامة لتتمية الثروة السمكية - 2006). 
ومن الناحيـة الاقتصـادية فإن إنتاجية الثروة السمكة منخفضـة التكاليف بالمقارنـة إلى تكلفة الإنتاج الحيواني في فروعه الأخرى كاللحوم الحمراء والدواجن حيث يصل معدل النمو الغذائي للكيلو

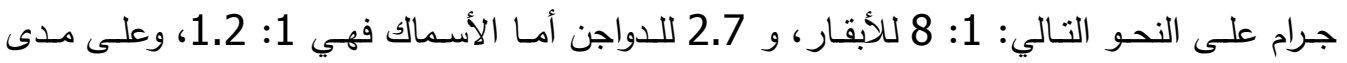

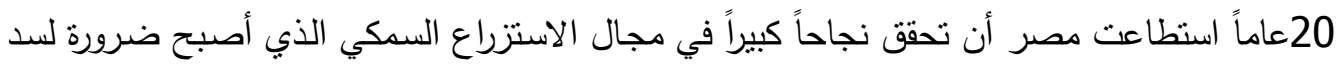
الفجوة الغذائية ومواكبة الزيادة السكانية حيث تبلغ إنتاجية الفدان في الاستزراع السمكي الجئي من 10 - 15 ضعف إنتاجية الفدان من المصادر الطبيعية.(http:/www.ahadeeqa.com)

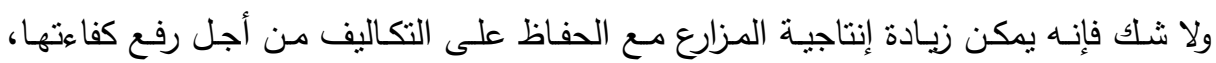
ويقتضـي ذللك تزويد المـربين بالمعـارف المتعلقة بحسـن استغلال المـزارع السـكية، وإكسابهم مهارة تساعدهم على العمليات الدورية واليومية الصحيحة باستخدام مصادر المعلومات المناسبة، وتوفير عدد بدان كافي من المرشدين في مجال الأسماك، الأمر الذي يحقق الاتصـال التعليمي الذي يهدف إلى الكى تعليم

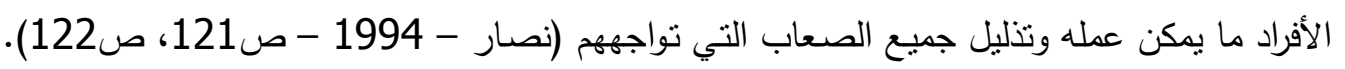

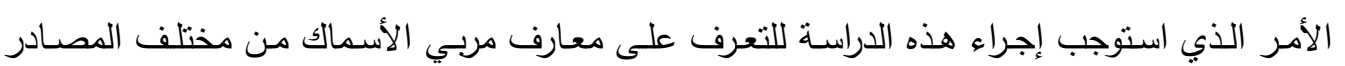

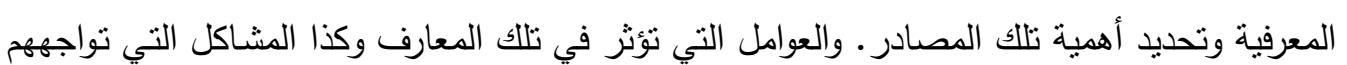
في هذا المجال.

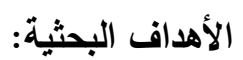
1- التعرف على مستوى معارف الزراع المكتسبة من مصادر المعلومات في عملية الاستزراع السمكي. 2- تحديد العلاقة الارتباطية بين السمات المميزة للمبحثوين ومعارفهم في عملية الاستزراع السمكي. 3- تحديد الأهمبة النسبية لعمليات الاستزراع السمكي. 4- تحديد الأهميـة النسبية لمصـادر المعلومـات التي يكتسبـ منهـا المبحوثين معـارفهم عن عمليـات الاستزراع السمكي. 5- تحديد المشاكل التي تواجه المبحوثين وكذا الحلول المناسبة لها من وجهة نظرهم.

جمعت البيانات الخاصة بالبحث من مربي الأسماك في مزارع مرخصة بقريتي دمرو وطلمبات

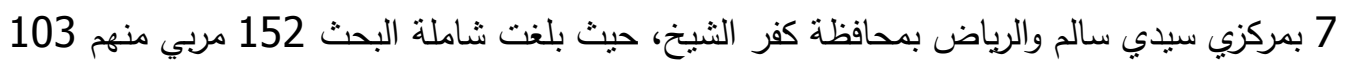

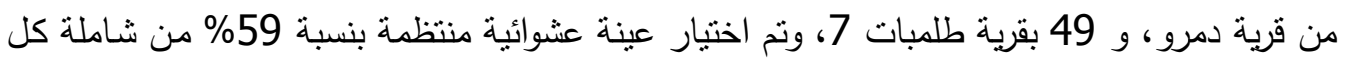
قرية وبذلك بلغ عدد أفراد العينة 89 مبحوثا - (60 مبحوثا بقرية دمرو و و29 مبحوثا بقرية طلمبات

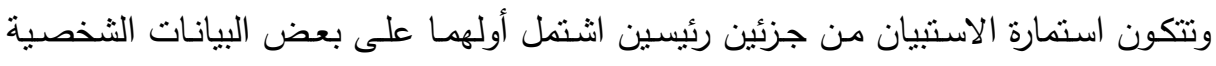

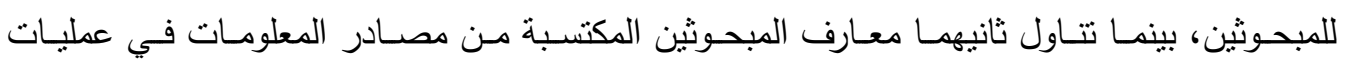

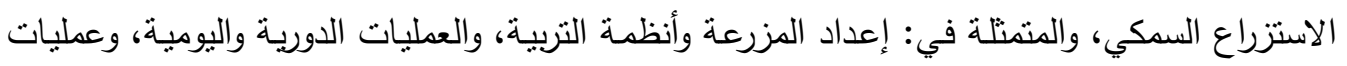
التسميد، والتغذية، وعملية التسويق والإنتاج. 
وجمعت البيانـات بالمقابلـة الشخصية مـع استخدام استمارة اسـتبيان أعدت خصيصـاً لهذا

الغرض وتم اختبارها مبدئيا بمقابلة 18 مبحوثا.

التعاريف والمفاهيم البحثية

المعرفة:

هي مجموعة من المعاني والمعتقدات والأحكام والمفاهيم والتصورات الفكريـة التي تتكون لدى الإنسان

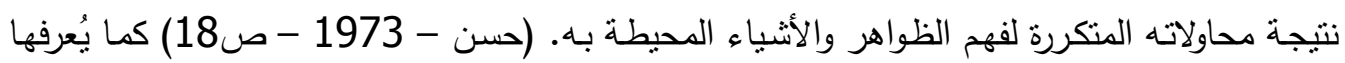

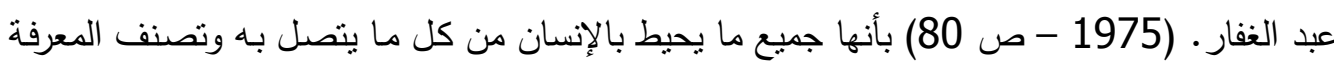
إلى ثلاثة أنواع هي: المعرفة الحسية، والمعرفة الفلسفية والمعرفة العلمية. الزباع: هم كل من يعمل في الاستزراع السمكي سواء كان مالكاً أو مستأجراً للمزرعة ويقوم بعمليات إعداد

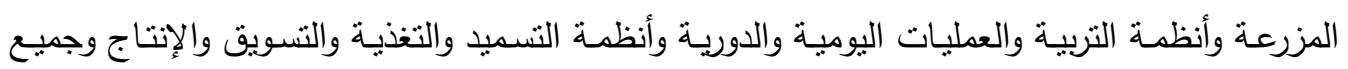

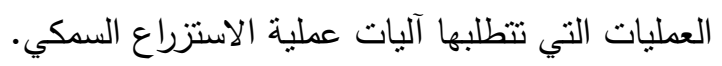
مصادر المعلومات:

هي التي يلجأ إليها الزراع للحصول على المعلومات المتعلقة بالتوصيات الفنيـة في عملية

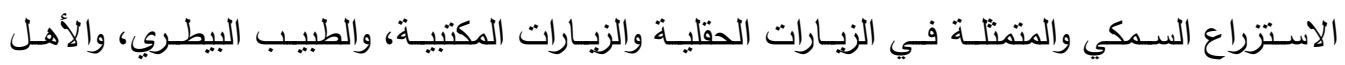

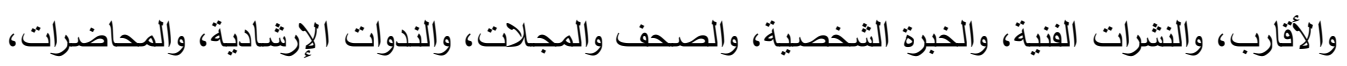
والبرامج الإذاعية، والاجتماعات الإرشادية، والإيضاحات العملية، والبرامج التليفزيونية.

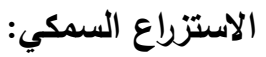

يقصد بـه تربية الأسماك في أحواض طينية من أجل التحكم في أعداد الأسماك في المتر المربع وكذا العمليات المختلفة من إعداد الأحواض حتى الجمع والتسويق.

أساسيات الاستزراع وإعداد المزرعة:

يقصد بها البيئة التي يعيش فيها الأسماك من درجة حرارة، ودرجة ملوحة، ودرجة PH، ونسبة الاكسجين في المياه، ونظم تغذية جيدة، والتخلص من الفضـلات، ومساحة الحوض المناسبة، ونسبة

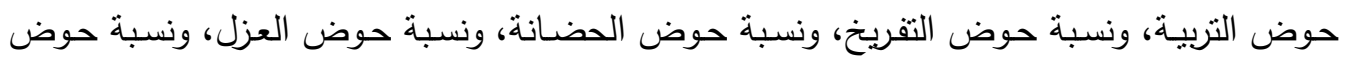
الإنتاج من مساحة الحوض الرئيسي.

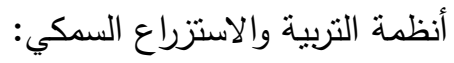
أسلوب يقصد به الاستزراع، ومزايا نظام التربية المفتوح، ومزايا نظام التربية المغلق. العمليات اليومية والدورية:

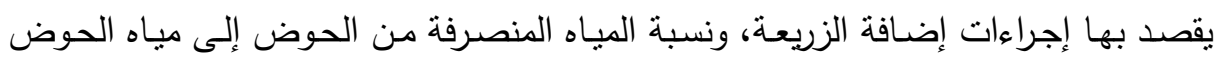

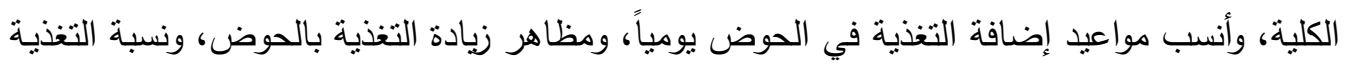

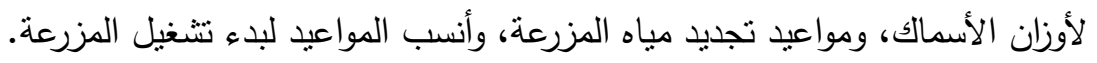


عملية التسميا والتغذية:

يقصـد بها أنـواع التسـميد المضـاف للحـوض، وطـرق إضـافة الأسـمدة العضـوية والكيماويـة، والتغذية التكميلية، وأنواع علائق التغذية، والمكونات الأساسية للعلائق المتكاملة، وطرق إضـافة التغذية، وطرق التغذية عند جمع الأسماك.

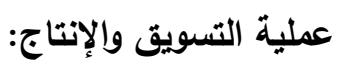

يقصد بها المدة المناسبة لدورة التربية، والوزن الاقتصادي عند الجمع، والكثافة المناسبة من الأسماك بحوض التربية، وتوقيت جمع الأسماك وتسويقها، وعدد الدورات المناسبة في العام، وأسماء ثلاثة أمراض شائعة، وطرق الوقاية من الأمراض، وكيفية التصرف الأند عند الإصابة بالأمراض. المتغيرات المستقلة وطرق قياسها:

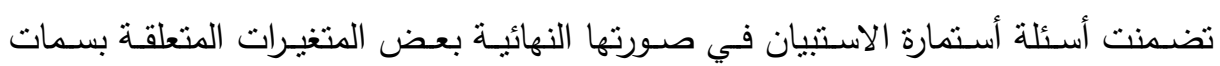

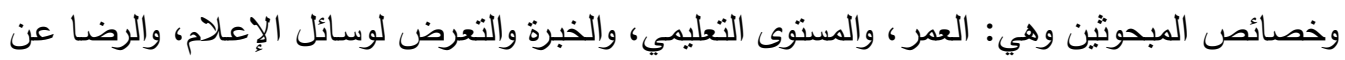

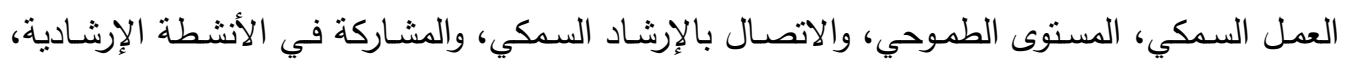

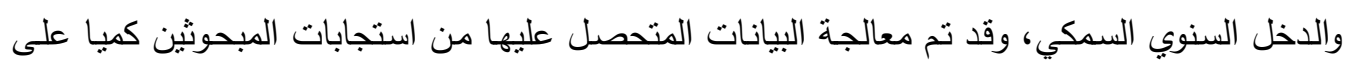
النحو التالي: العمر:

نم قياسه بعدد سنوات عمر المبحوث لأقرب سنة ميلادية وقت إجراء الدراسة.

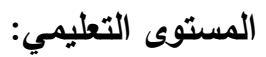

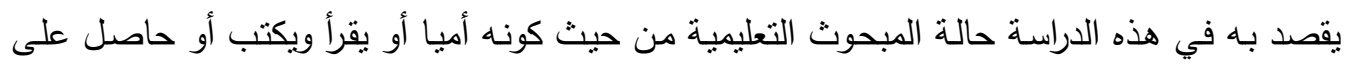

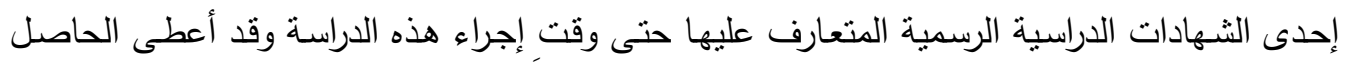
على مؤهل منوسط ثناث درجات، ومن يقرأ ويكتب بدون حصوله على شهادة رسمية درجتان والأمسي درجة واحدة.

\section{الخبرة في الاستزلاع السمكي:}

نم قياسها بعدد السنوات التي قضاها المبحوث في أعمال الاستزراع السمكي.

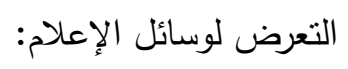

يقصـد بها في هذه الدراسـة تكرار استماع المبحوث للراديو، ومثــاهدة التلفزيون، ومطالعـة الصحف ودرجة الاستفادة من هذه الوسائل ومعرفة ثنلاث من البرامج المسموعة أو المشاهدة أو المقرؤه

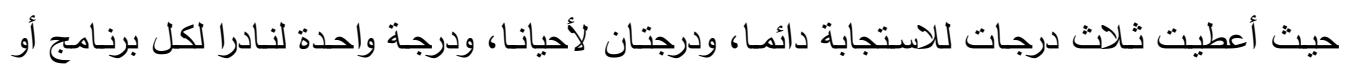

هي مشاعر النجاح أو الفشل في العمل بالاستزراع السمكي الذي يزاوله المبحوث حيث أعطيت درجتان لمشاعر النجاح المرتفعة، ودرجة واحدة لمشاعر النجاح المنخفضة. 
هو ما أنجزه المبحوث من نوصيات فنية متفوقا عن أقرانه من المبحوثين، وثم قياسه بإعطاء درجتان للإنجاز الدائم، ودرجة واحدة للإنجاز أحيانا.

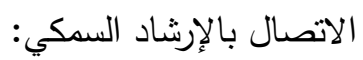
يقصد بها في هذه الدراسة معرفة المبحوث للمرشد والاتصال به ومدى تردده عليه ومدى الاستفادة منه، وقد أعطيت ثلاثة درجات للاستجابة المرتفعة ودرجتان للاستجابة المنوسطة ودرجة واحدة للاستجابة الضعيفة. المشاركة في الأنشطة الإرشادية: يقصد بها في هذه الدراسـة تكرار مشـاركة المبحوثين في مختلف الأنشطة الإرشـادية، وقد أعطيت للمشاركة الدائمة ثلاث درجات، والمشاركة أحيانا درجتان، والمشاركة نادراً درجة واحدة.

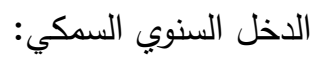
يقصد به صافي الدخل من المزرعة السمكية في العام بالجنيه.

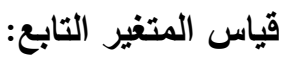
تم قياس معلومات الزراع المبحوثين المتعلقة بأربعة وسنون توصية متعلقة بعمليات الاستزراع السمكي

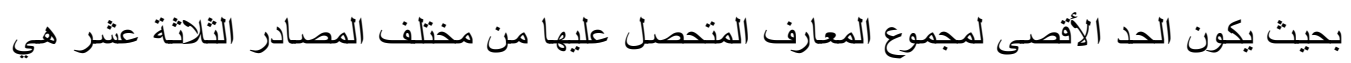

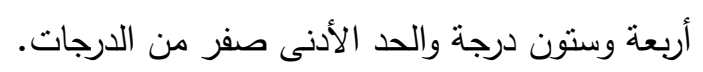

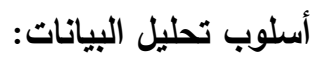
تم الاستعانة بالأساليب الإحصائية التالية: النسب المئوية، ومعامل تحليل ألفا، ومعامل الارتباط البسيط ليبرسون، ومعامل الانحدار المتعدد كأساليب إحصائية. النتائج والمناقشة:

\section{أولاً: ثبات مقياس معارف المبحوثين بعملية الاستزراع السمكي.}

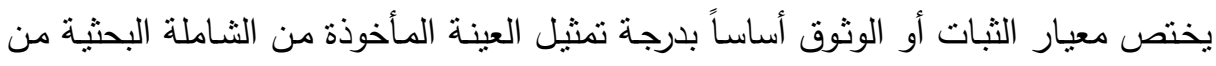

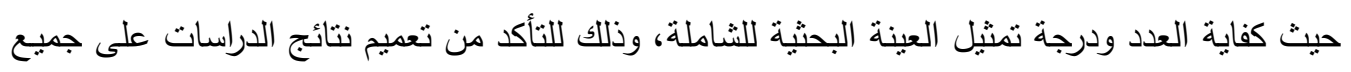
أفراد الشاملة، ويمكن الوثوق في النتائج المتحصل عليها إذا أعطيت نفس النتائج أو نتائج مشابهة في في

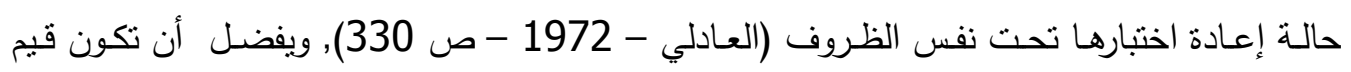
معامل ألفا بين 0.5 - أقل من واحد صحيح لأن هذه القيم تعطى للمقياس درجة ثنات أكبر .

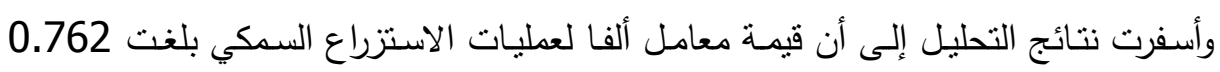

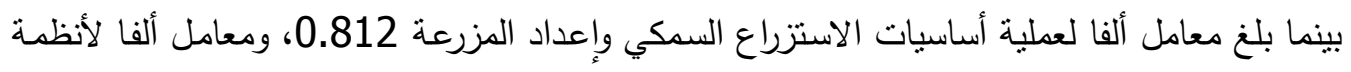
التربية والاستزراع السمكي 0.758 ومعامل ألفا للعمليات اليومية والدورية 0.747 ومعامل ألفا لعملية التسميد والتغذيـة ومعامل ألفا لعملية التسويق والإنتاج 0.824، وبنـاء على أسلوب تحليل ألفا يكون المقياس ثابتاً وموثوق في نتائجه المتحصل عليها وصالح لتعميم تلك النتائج على الثاملة. ثانياً: الخصائص المميزة للمبحوثين. العمر : ترجع أهميـة معرفة العمر لأن لله صلة قويـة بحيويـة ونشـاط المبحوثين في مختلف الميـيادين الحياتية (هلول وآخرون - 1961 - ص 326)، ويذكر العادلي • (مرجع سابق - ص 222) وصالح 
آخرون • (2004 - ص 326) أن الأفراد من صغار ومتوسطي العمر يكونون أكثر استعدادا وتقبلا للأفكار والأساليب الزراعية الحديثة من كبار العمر.

وأوضحت النتائج بجدول (1) أن نسبة المبحوثين صغار العمر بلغت العبه العهر 53.93\% وكبـار العــر 8\% الأمـر الذي يوضـح أن نسبة الصـغار ومنوسطي العـر بلغت 91\%، الأمر الذي يوضح استعدادهم وتقبلهم للأفكار والأساليب الزراعية الحديثة.

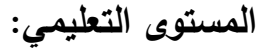
يعكس المستوى التعليمي نوعية المورد البشري فالطاقات البشرية وتوجيهها بلغت دورا رئيسيا وحيويا في

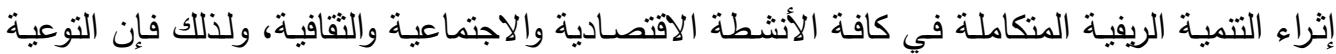

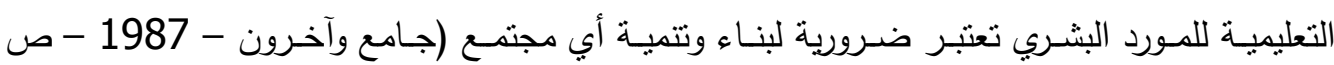

وأوضـحت النتائج أن نسبة المبحـثين الأميين بلغت 35.95\%، ويقرأ ويكتب 16.85\% والحاصل على شهادة منوسطة 47.20\% ، ويتضح من تلك النتائج أن من لم يحصلوا على شهادة

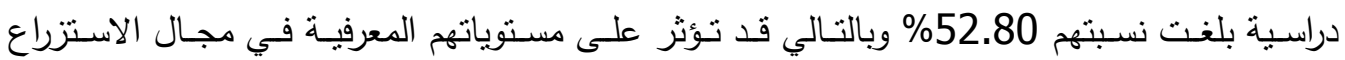
السكي، ويعكس ذلك ارتفاع نسبة الأمية نسبياً بين المبحوثين.

جدول رقم 1. بعض الخصائص المميزة للمبحوثين

\begin{tabular}{|c|c|c|c|c|c|}
\hline$\%$ & 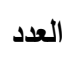 & المتغيرات المدروسة & $\%$ & العدد الع & المتغيرات المدروسة \\
\hline & & التعرض لوسائل الإعلام & & & 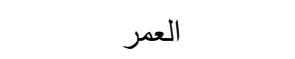 \\
\hline 16.85 & 15 & منخفض (3درجات فأقل) & 37.08 & 33 & (27 - 27 4سنة) \\
\hline 78.65 & 70 & متوسط (4 - 7درجات) & 53.93 & 48 & (44 - 60سنة) \\
\hline 4.49 & 4 & مرتفع (8- 11 درجة) & 8.98 & 8 & (61) - 61 - \\
\hline \multirow[t]{2}{*}{100} & 89 & الجملة & 100 & 89 & الجملة \\
\hline & & الرضـا عن العمل السمكي & & & المستوى التطليمي \\
\hline 19.11 & 17 & منخفض(11-14درجة) & 35.95 & 32 & أمي \\
\hline 29.21 & 26 & متوسط(15-17 درجة) & 16.85 & 15 & يقرأ ويكتب \\
\hline 51.68 & 46 & مرتفع(18-20درجة) & 47.20 & 42 & حاصل على شهادة دراسية \\
\hline
\end{tabular}




\begin{tabular}{|c|c|c|c|c|c|}
\hline 100 & 89 & الجملة & 100 & 89 & الجملة \\
\hline & & السمتوى الطموحي & & & الخبرة في الاستزراع السمكي \\
\hline 6.74 & 6 & منخفض (12 - 16) & 24.72 & 22 & منخفضة (5- 14درجات) \\
\hline 33.71 & 30 & منوسط (17- 26 درجة) & 48.31 & 43 & منوسطة ( 15-24 درجة) \\
\hline 59.55 & 53 & مرتفع (27 - 33 درجة) & 26.97 & 24 & مرتفعة (25 -32 درجة) \\
\hline \multirow[t]{2}{*}{100} & 89 & الجملة & 100 & 89 & الجملة \\
\hline & & الاتصال بالإرشاد السمكي & 100 & 89 & السعة الحبازية السمكية \\
\hline 15.73 & 14 & منخفض (3درجات فأقل) & 79.77 & 71 & صغيرة (1-12فدان) \\
\hline 61.79 & 55 & منوسط (4-7 درجات) & 13.48 & 12 & متوسطة (13- 24فدان) \\
\hline 22.48 & 20 & مرتفع (8درجات فأكثر) & 6.75 & 6 & كبيرة (25-34فدان) \\
\hline 100 & 89 & الجملة & 100 & 89 & الجملة \\
\hline
\end{tabular}

تابع جدول رقم 1.

\begin{tabular}{|c|c|c|c|c|c|}
\hline & & الدخل السنوي السمكي & & & المشاركة في الأنثطة الإرشادية \\
\hline 56.18 & 50 & منخفض(1-7آلاف جنيه) & 31.46 & 28 & منخفض (3 درجات فأقل) \\
\hline 33.71 & 30 & منوسط (8-14ألف جنيه) & 49.43 & 44 & منوسط (4-7 درجات فأقل) \\
\hline 10.11 & 9 & مرتفع(15-17ألف جنبه) & 19.11 & 17 & مرتفع (8درجات فأكثر) \\
\hline 100 & 89 & الجملة & 100 & 89 & الجملة \\
\hline
\end{tabular}

\section{الخبرة في الاستزلاع السمكي:}

يعد التراكم المعرفي والمهاري التقني مصدرا هاماً لتكوين الخبرات الفنية والتي يمكن استغلالها

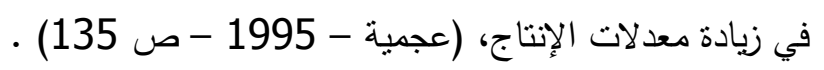

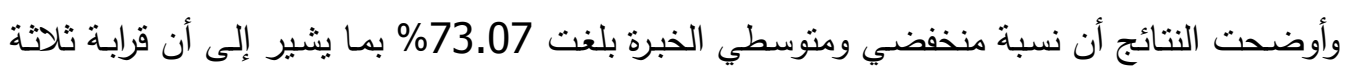
أرباع المبحوثين في احتياج معرفي لقلة خبراتهم في الاستزراع السمكي.

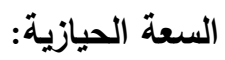

لا ريب أن تبني المبتكرات التكنولوجية الجديدة يلازمه وجود عنصر المخاطرة، كما أن الزراع

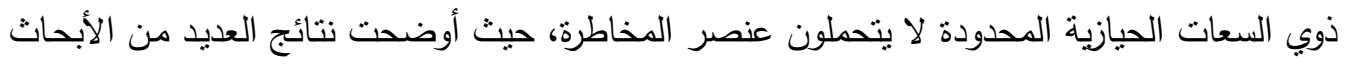

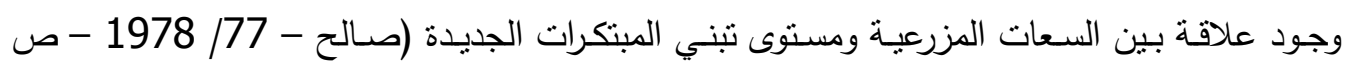

أوضحت النتائج أن نسبة ذوي الحيازات الصغيرة بلغت 79.7\% الامر الذي يحد من عناصر

$$
\text { المخاطرة في تبني المستحدثات، مما يؤثز على الإنتاج. }
$$

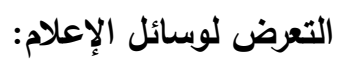

تشير الدراسـات أن نسبة تغيرسلوك الأفراد يزداد بزيادة التعرض لوسـائل الإعلام أي تكرار الاستماع

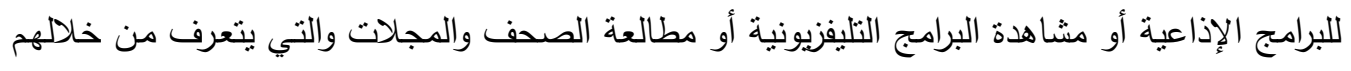


المبحوث على مزيد من المعارف العامة والخاصة التي تمكنه من حرية اتخاذ القرارات المختلفة بطريقة سليمة وصحيحة.

وأوضحت النتائج أن نسبة المبحوثين منخفضي ومتوسطي التعرض بلغت نسبتهم 95.1\%، تونة وهي نسبة كبيرة تؤثز على معارف المبحوثين، كما تشير إلى ضعف الجهود الإرشادية الزراعية في

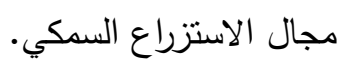

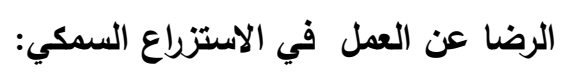
إن رضا المبحوث عن العمل الذي يعمل فيه نتيجة الثعور بالسعادة يجعله يبذل أقصى جهد مدكن في المئي

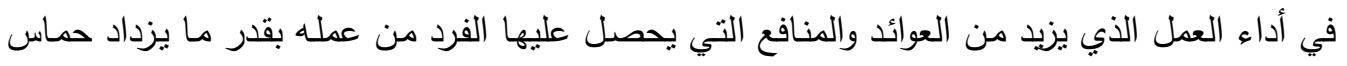

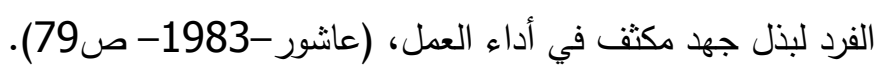

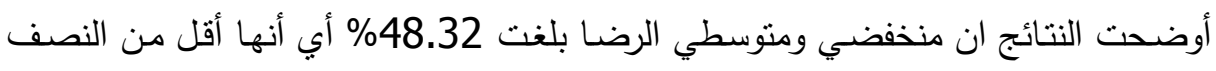

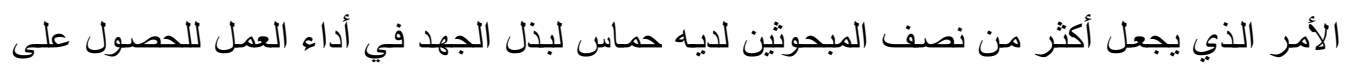
عوائد متزايدة من الاستزراع السمكي عن طريق زيادة الإنتاج.

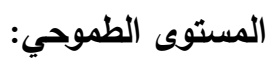

عرفه عاشور - (مرجع سابق صماني") على أنه مستوى الإنجاز المرتقب الذي يحاول الفرد

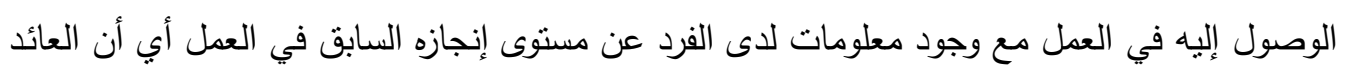

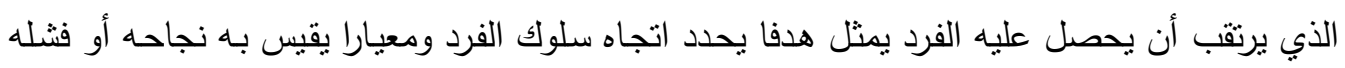
فيما حققه فعلاً. وأوضـت النتائج أن منخفضـي ومتوسطي الطهوح بلغت 40.45\% أي أنها تمثل قرابـة ثلث عدد المبحوثين الأمـر الذي يجعل قرابـة من ثلثي المبحوثين لديهم طموح يؤدي إلى حـالات من النجـاح

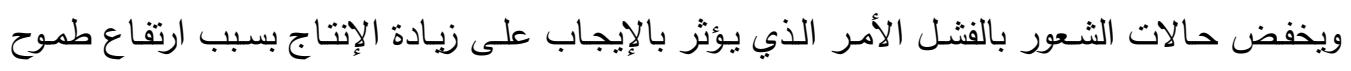
العاملين.

\section{الأتصال بالإرشاد السمكي:}

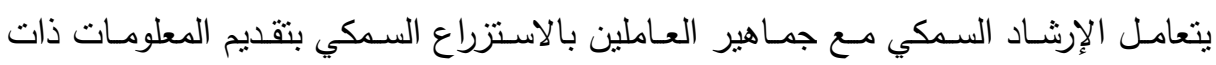

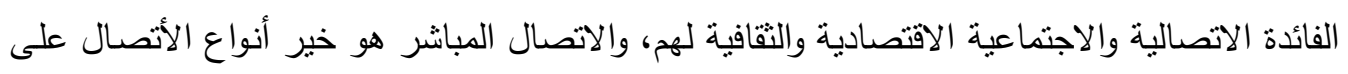

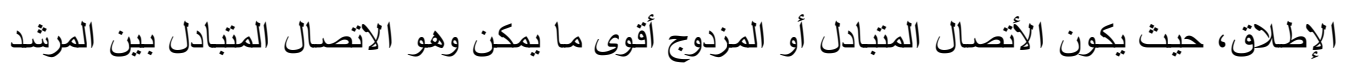

$$
\text { والمسترشدين (عبد الغفار - مرجع سابق - ص الإس 230). }
$$

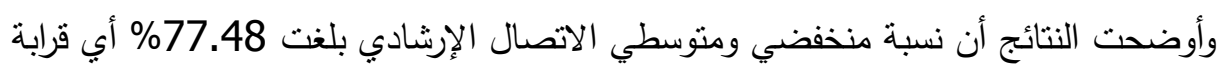

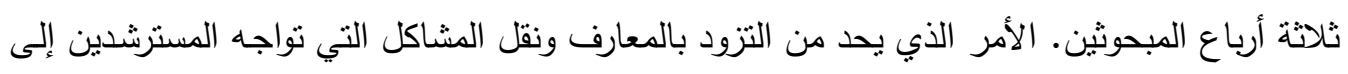

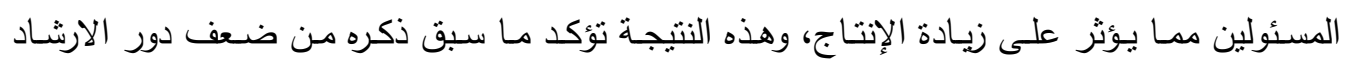
الزراعي في الاستزراع السمكي. المشاركة في الأنشطة الارشادية: 
لا ريـب أن المسترشـــ الـذي يكـرر الششـاركة في الأنشـة الإرثـادية يكـون أكثر إلمامـا بالمعلومات والأفكار الزراعية العصرية أكثر من المسترشد الذي لا يتعرض لتلك الأنشطة الإرشادية ويكون أكثر تقبلا وتننياً للمستحدنات الزراعية لزيادة الإنتاج والدخل.

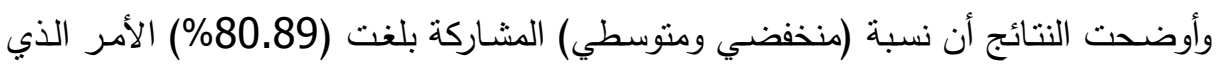

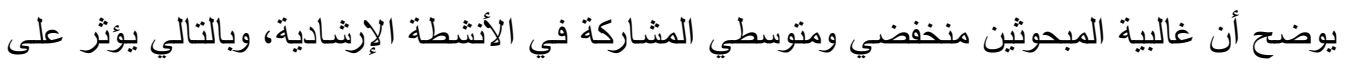
تقبلهم وتبنيهم المستحدثات التي تؤدي لزيادة الإنتاج والدخل معاً.

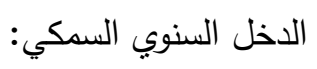
إن الدخل من أهم مؤثرات تحديد الطبقة الاجتماعية وبزيادة الدخل بزداد استمرار الفرد في النشاط الذي يؤديه وينتشر العمل فيه. وأوضحت النتائج أن نسبة (منخفضي ومنوسطي) الدخول بلغت (89.89\%) أي أن غالبية

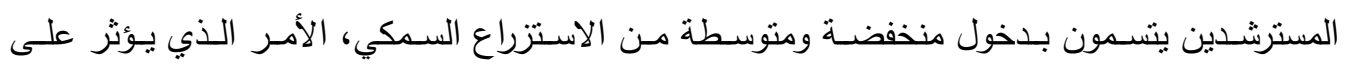
الاستمرار في النشاط والعمل على زيادة الإنتاج.

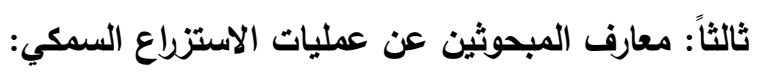
يحتوي المستوى المعرفي للمبحوثين على المعارف في عملية الاستزراع السمكي والتي تتضمن خمس عمليات هي: أساسيات الاستزراع السمكي وإعداد المزرعة السمكية، وأنظمة التربية، والعمليات اليومية والدورية، وأنظمة التسميد والتغذية، وعمليةالتسويق والإنتاج.

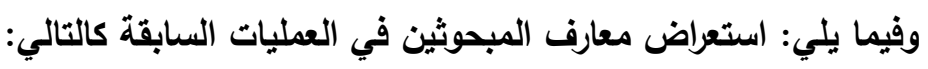

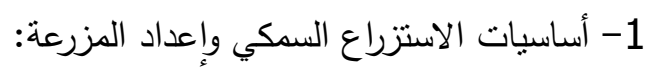

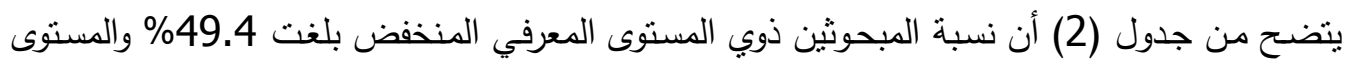
المتوسط بلغت 41.6\% والمستوى المرتفع 9\% بـ وهذا يوضتح انخفاض معارف المبحوثين في عملية

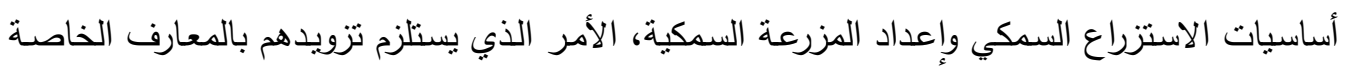

جدول رقم 2. معارف المبحوثين عن عملية وأساسيات الاستزراع السمي وإعداد المزرعة

\begin{tabular}{|c|c|c|}
\hline$\%$ & العدد & مستوى المعارف \\
\hline 49.4 & 44 & منخفض (2 - 6 درجة) \\
\hline 41.6 & 37 & متوسط (7 - 11 درجة) \\
\hline 9.0 & 8 & مرتفع (12 - 14 درجة) \\
\hline 100 & 89 & الإجمالي \\
\hline
\end{tabular}

ويوضـح جـول (3) نسبة معـارف المبحوثين لكل توصيه مـن التوصيات المتعلقة بعمليـة أساسيات الاستزراع السمكي وإعداد المزرع السمكية حيث كانت أعلى استجاب هي معرفة درجة حرارة المزرعة حيث بلغت نسبتها 84.0\%، وأقل استجابة كانت معرفة نسبة مساحة حوض العزل من حوض التربية 
جدول رقم 3. معارف المبحوثين بأساسيات الاستزراع السمكي وإعداد المزرعة

\begin{tabular}{|c|c|c|c|c|c|}
\hline$\%$ & ل لا يعرف & $\%$ & يعرف & البيـان & 5 \\
\hline 15.7 & 14 & 84.3 & 75 & درجة الحرارة للمزرعة & 1 \\
\hline 20.3 & 18 & 79.8 & 71 & درجة الملوحة للمزرعة & 2 \\
\hline 59.6 & 53 & 40.4 & 36 & 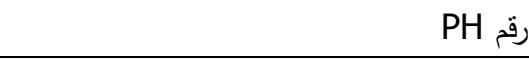 & 3 \\
\hline 31.5 & 28 & 68.5 & 61 & كمية الأكسجين بالمزرعة & 4 \\
\hline 19.1 & 17 & 80.9 & 72 & كمية التغذية بالمزرعة & 5 \\
\hline 21.4 & 19 & 78.7 & 70 & التخلص من فضلات المزرعة & 6 \\
\hline 22.5 & 21 & 77.5 & 69 & المساحة المفضلة لإنثاء حوض تربية الأسماك & 7 \\
\hline 59.6 & 53 & 39.3 & 35 & نسبة مساحة حوض الأمهات من حوض التربية & 8 \\
\hline 58.4 & 52 & 41.6 & 37 & نسبة مساحة حوض التفريخ من حوض التربية & 9 \\
\hline 25.9 & 23 & 74.2 & 66 & نسبة مساحة حوض الحضانة من حوض التربية & 10 \\
\hline 66.9 & 56 & 37.1 & 33 & نسبة مساحة حوض العزل من حوض التربية & 11 \\
\hline 53.9 & 48 & 46.1 & 41 & نسبة دساحة حوض الإنتاج من حوض التربية & 12 \\
\hline
\end{tabular}

بناءً على ما سبق بتضح ضرورة تخطبط برامج إرشادية تتناول البنود المعرفية ذات المعرفة

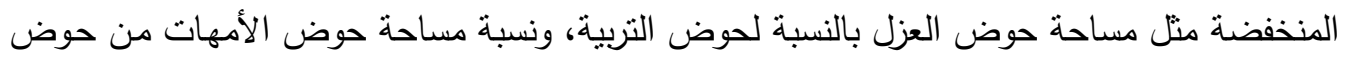

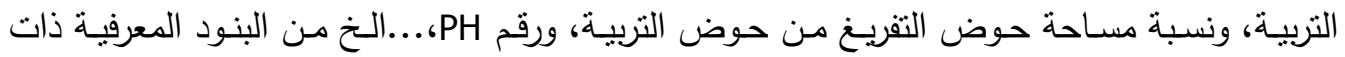
المعرفة المنخفضة.

وللتعرف على العلاقة الارتباطية بين خصـائص المبحوثين و أساسيات الاستزراع السمكي وإعداد المزرعة فإن النتائج بجدول (4) توضـح وجود علاقة ارتباطية موجبة عند المستوى الإحتمالي 01، بين كل من المستوى التعليمي 0.449 والخبرة في المزارع السمكية 0.699 والرضا عن العمل فئل

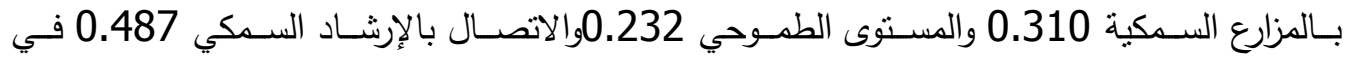
المشاركة في الأنشطة الإرشادية 0.301 وبين عملية أساسيات الاستزراع السمكي وإعداد المزرعة، كما توجد علاقة ارتباطية معنوية عند المستوى الاحتمالي 0.05 بين المتغير التابع ومتغيري السعة الحيازية الإنية

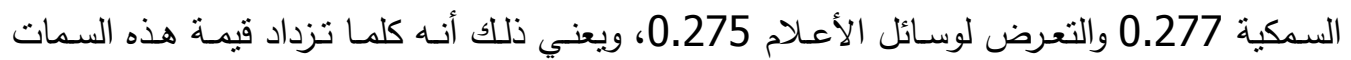

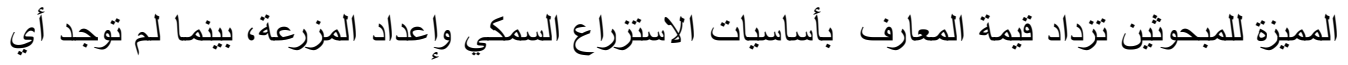

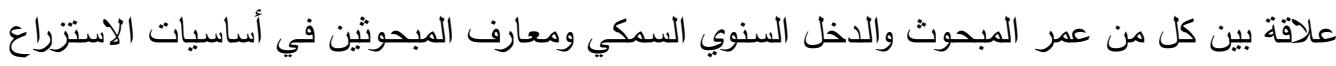
السمكي وإعداد المزرعة.

جدول رقم 4. المتغيرات المرتبطة بمعارف المبحوثين في عملية أساسيات الاستزلاع السمي:

\begin{tabular}{|c|c|c|}
\hline مستوى المعنوية & قيم معاملات الارتباط البسيط & المتغيرات \\
\hline غير معنوي & 0.181 & العمر - العر \\
\hline 0.01 & $* * 0.449$ & المستوى التعليمي \\
\hline 0.01 & $* * 0.669$ & الخبرة في المزارع السمكية \\
\hline
\end{tabular}




\begin{tabular}{|c|c|c|}
\hline 0.05 & $* 0.277$ & السعة الحيازية السمكية \\
\hline 0.05 & $* 0.275$ & التعرض لوسائل الإعلام \\
\hline 0.01 & $* * 0.310$ & الرضا عن العمل بالمزارع السكية \\
\hline 0.05 & $* 0.232$ & المستوى الطموحي بالمزارع السمكية \\
\hline 0.01 & $* * 0.478$ & الاتصال بالإرشاد السمكي \\
\hline 0.01 & $* * 0.301$ & المشاركة في الأنشطة الإرشادية \\
\hline 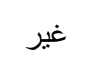 & 0.97 & الدخل السنوي السمكي \\
\hline \multicolumn{3}{|c|}{ معنوي عند 0.01 معنوي عند0.05 } \\
\hline
\end{tabular}

جدول رقم 5. معاملات الاتحدار بين المتغيرات المستقلة ومعارف المبحوثين في أساسيات الاستزراع

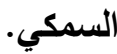

\begin{tabular}{|c|c|c|c|}
\hline 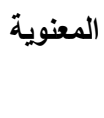 & $ت$ & معامل الانحدار الجزئي & المتغيرات \\
\hline- & 1.027 & 0.092 & 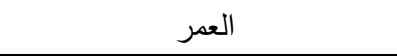 \\
\hline- & 0.860 & 0.100 & المستوى التعليمي \\
\hline 0.01 & 5.544 & 0.445 & الخبرة في المزارع السمكية \\
\hline 0.01 & 3.692 & 0.523 & نوع الحيازة السمكية \\
\hline- & 0.809 & 0.059 & السعة الحيازية السمكية \\
\hline- & 0.802 & 0.120 & التعرض لوسائل الإعلام \\
\hline 0.05 & 2.007 & 0.220 & الرضا عن العمل بالمزارع السمكية \\
\hline- & 0.232 & 0.022 & المستوى الطموحي بالمزارع السمكية \\
\hline- & 0.312 & 0.054 & الاتصال بالإرشاد السمكي \\
\hline 0.05 & 2.151 & 0.198 & المشاركة في الإنشطة الإرشادية \\
\hline- & 0.487 & 0.048 & الدخل السنوي السمكي \\
\hline \multicolumn{4}{|c|}{$0.721^{2}}$, \\
\hline
\end{tabular}

وبناءً على ذلك فإنه يجب تخطيط برامج إرشادية تستهدف زيادة معارف مربي الأسماك بكيفية

إعداد المزرعة مع الأخذ في الاعتبار المتغيرات المرتبطة بتلك العملية والمؤثرة عليها. وللتعرف على تأثير المتغيرات المستقلة على معارف المبحوثين في عملية الاستزراع السمكي

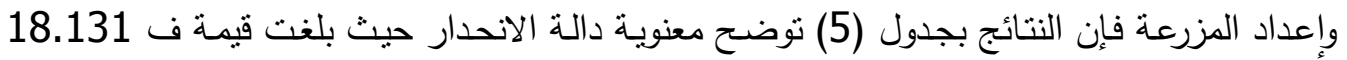

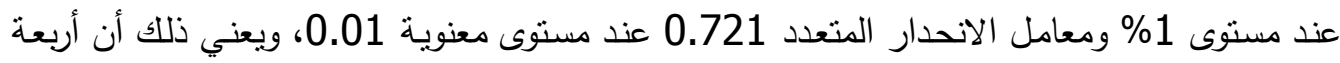
متغيرات (السمات المميزة للمبحوثين) ذات تأثنير واضح في عملية أساسيات الاستزراع السمكي وإعداد المزرعة بنسبة (72.1\%)، وباقي التأثير يرجع إلى عوامل أخرى، وهذه المتغيرات هي:

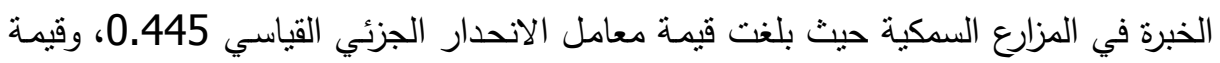
"ت" 4.544، وهي قيمة معنوية عند المستوى الاحتمالي 0.01 أما متغيري الرضا عن العمل بالمزارع 
السمكية 0.22، و 2.007، والمشـاركة في الأنشطة الارشـادية 0.198، و 2.151 فهما ذات تأثثر معنوي عند المستوى الاحتمالي 0.05. 2- أنظمة التربية والاستزراع السمكي: يتضح من جدول (6) أن نسبة المبحوثين ذوي المسنوى المنخفض بلغت 11.2\% والمسنوى المنوسط

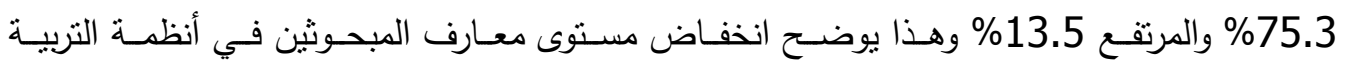
والاستزراع السمكي الأمر الذي يستلزم تزويدهم بالمعارف الخاصة بتلك العملية لزيادة الانتاج والدخل. جدول رقم 6. معارف المبحوثين عن أنظمة التربية والاستزراع السمكي

\begin{tabular}{|c|c|c|}
\hline$\%$ & 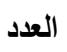 & مستوى المعارف \\
\hline 11.2 & 10 & منخفض (1-3 درجة) \\
\hline 75.3 & 67 & متوسط (4 - 6 درجة) \\
\hline 13.5 & 12 & مرتقع (7 - 9 درجة) \\
\hline 100 & 89 & الجملة الجما \\
\hline
\end{tabular}

ويوضـح جدول (7) نسبة معـارف المبحوثين لكل توصـية مـن التوصـيات المتعلقة بأنظمـة التربية والاستزراع السمكي حيث كانت أعلى استجابة معرفة الإنتاج المضـاعف حيث بلغت نسبتها

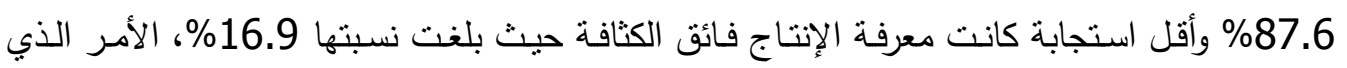
يستوجب ضرورة تزويد المبحوثين بمزيد من المعارف في عملية أنظمة التربية والاستزراع السمكي.

جدول 7. معارف المبحوثين بأنظمة التربية والاستزراع السمكي.

\begin{tabular}{|c|c|c|c|c|}
\hline$\%$ & لا يعرف & $\%$ & يعرف & 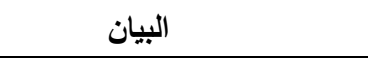 \\
\hline 50.8 & 43 & 51.1 & 46 & الإنتاج المنسع \\
\hline 33.7 & 30 & 66.3 & 59 & الإنتاج شبه المكثق \\
\hline 27.0 & 24 & 73.0 & 65 & الإنتاج المكثق \\
\hline 83.2 & 74 & 16.9 & 15 & الإنتاج فائق الكثافة \\
\hline 5.6 & 5 & 94.4 & 64 & مزايا نظام تربية الأسماك المفتوح \\
\hline 38.2 & 34 & 61.8 & 55 & الإنتاج طوال العام \\
\hline 12.4 & 11 & 87.6 & 78 & الإنتاج المضاعف \\
\hline 13.5 & 12 & 86.5 & 77 & الإنتاج بحالة جيدة \\
\hline
\end{tabular}

وللتعرف على العلاقة الارتباطية بين العوامل المميزة للمبحوثين وأنظمـة التربيـة والاستزراع السمكي فإن النتائج بجدول (8) تشير إلى وجود علاقة ارتباطية موجبة بين كل من: التعرض لوسائل

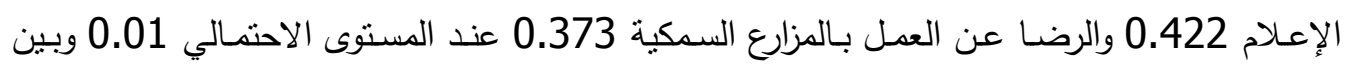


العمر 0.245 والدخل السنوي السمكي 0.245 والمتغير التابع عند المستوى الاحتمالي 0.05 ويعني

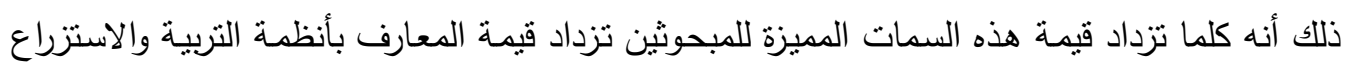
السمكي بينما لم توجد أي علاقة بين المتغير التابع وباقي المتغيرات المستقلة المدروسة. جدول رقم 8. المتغيرات المرتبطة بمعارف المبحوثين في أنظمة التربية والاستزراع السمكي

\begin{tabular}{|c|c|}
\hline قيم معاملات الارتباط البسيط & المتغيرات \\
\hline$* 0.245$ & 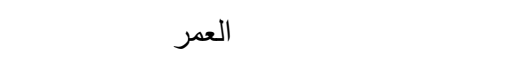 \\
\hline 0.08 & المستوى التعليمي \\
\hline 0.043 & الخبرة في المزارع السمكية \\
\hline 0.074 & السعة الحبازية السمكية \\
\hline$* * 0.422$ & التعرض لوسائل الإعلام \\
\hline$* * 0.373$ & الرضا عن العمل بالمزارع السمكية \\
\hline 0.198 & ل المستوى الطموحي \\
\hline 0.094 & الاتصال بالإرشاد السمكي \\
\hline 0.104 & الششاركة في الأنشطة الإرشادية \\
\hline$* 0.245$ & الدخل السنوي السمكي \\
\hline & * * معنوي عند010 * معنوي عند 5.01 \\
\hline
\end{tabular}

جدول رقم 9. معاملات الانحدار بين المتغيرات المستقلة ومعارف المبحوثين عن أنظمة التربيـة والاستزراع السمكي.

\begin{tabular}{|c|c|c|c|}
\hline مستوى المعنوية & $ت$ & معامل الانحدار القياسي & المتغيرات \\
\hline غير معنوي & 0.063 & 0.700 & 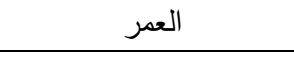 \\
\hline غير معنوي & 0.984 & 0.146 & الكستوى التعليمي \\
\hline غير معنوي & 0.211 & 0.027 & الخبرة في المزارع السمكية \\
\hline 0.05 & 2.027 & 0.369 & نوع الحيازة السمكية \\
\hline
\end{tabular}

تابع جدول رقم 9.

\begin{tabular}{|c|c|c|c|}
\hline 0.01 & 2.726 & 0.525 & السعة الحيازية السمكية \\
\hline 0.01 & 4.295 & 0.829 & التعرض لوسائل الإعلام \\
\hline 0.05 & 3.180 & 0.449 & الرضـا عن العمل بالمزارع السمكية \\
\hline 0.05 & 2.305 & 0.280 & المستوى الطموحي \\
\hline 0.01 & 3.812 & 0.852 & الاتصال بالإرشاد السمكي \\
\hline غير معنوي & 0.427 & 0.051 & المشاركة في الأنشطة الإرشادية \\
\hline
\end{tabular}




\begin{tabular}{|c|c|c|c|c|}
\hline غير معنوي & 1.189 & 0.149 & \multicolumn{2}{|c|}{ الدخل السنوي السمكي } \\
\hline & & $0.539={ }^{2}$, & معنوي 0.01 & ف= 8.193 \\
\hline
\end{tabular}

وللتعرف على تأثير الدتغيرات المستقلة الددروسة على الدتغير التابع فإن النتائج بجدول (9) تثير إلى معنوية دالة الانحدار المتعدد حيث بلغت قيمة ف

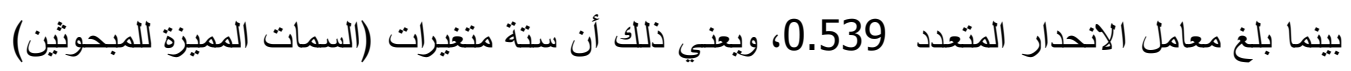

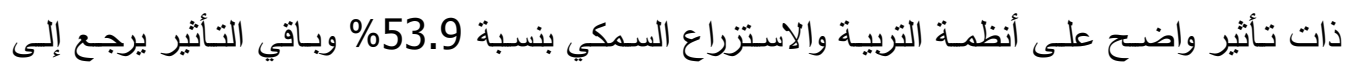
متغيرات أخرى، وإن المتغيرات المؤثرة هي:

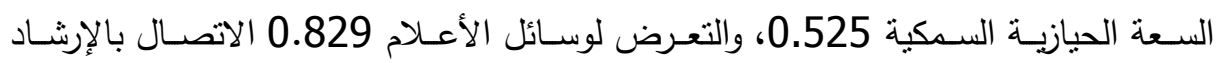

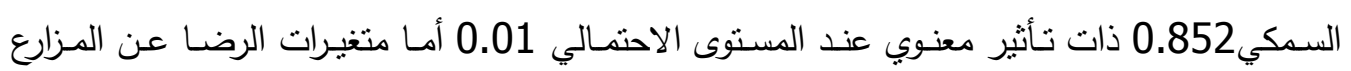

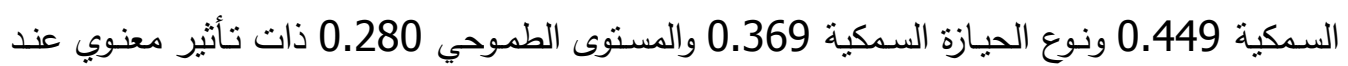
المستوى الاحتمالي 0.05. وهذه النتائج تبين أهمية إعداد مرثند متخصص في الاستزراع السمكي مع الاهنمام بإعداد برامج تليفزيونية في هذا المجال.

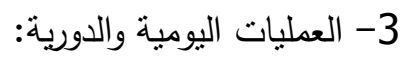

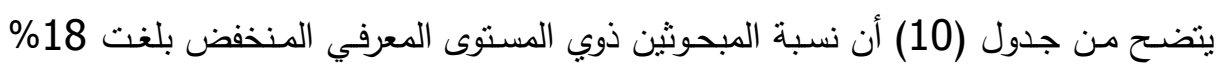

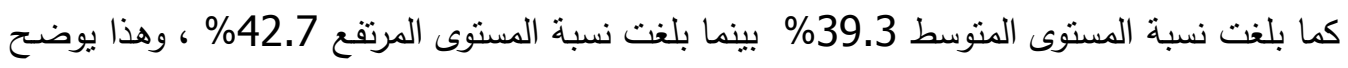

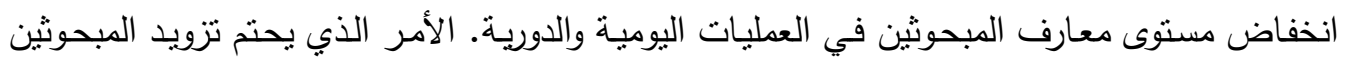
بالمعارف الخاصة بنلك العملية.

جدول رقم 10. معارف المبحوثين عن العمليات اليومية والدورية.

\begin{tabular}{|c|c|c|}
\hline$\%$ & العدد الع & مستوى المعارف \\
\hline 18 & 16 & منخفض (6 - 7 درجة) \\
\hline 39.3 & 35 & متوسط (8 -9 درجة) \\
\hline 42.7 & 38 & مرتفع (10 - 12 درجة) \\
\hline 100 & 89 & الجملة \\
\hline
\end{tabular}

بناءٌ على ما سبق فإنه يجب تخطيط برامج إرشادية تتناول أنظمة التربية مع مراعاة المتغيرات ذات الارتباط والثأثير المنوي في الاعتبار .

ويوضح جدول (11) نسبة معارف المبحوثين لكل توصية من التوصيات المتعلقة بالعطليات

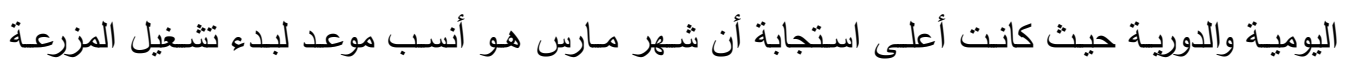

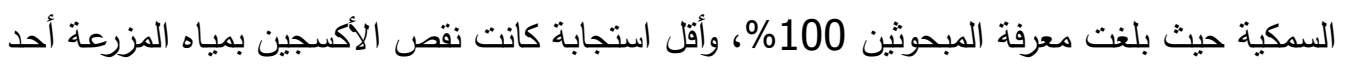
علامات زيادة كمية التغذية بحوض الإنتاج حيث بلغت نسبة المعرفة 51.68\% 


\begin{tabular}{|c|c|c|c|c|c|}
\hline$\%$ & لا يعرف & $\%$ & يعرف & البيـان & م \\
\hline 13 & 1 & 98.9 & 88 & إجراءات إضافة الزريعة لمياه المزرعة & 1 \\
\hline 18 & 6 & 82.0 & 73 & يفضل عند صرف مياه حوض التربية مراعاة حجم المياه المفرغة & 2 \\
\hline 7.9 & 7 & 92.1 & 82 & أنسب مواعيد إضافة التغذية في اليوم & 3 \\
\hline- & - & - & - & مظاهر زيادة كمية التغذية بالحوض & 4 \\
\hline 48.3 & 43 & 51.7 & 46 & نقص الأكسجين & 5 \\
\hline 1.1 & 1 & 98.9 & 88 & وجود رائحة عفنة & 6 \\
\hline 1.1 & 1 & 98.9 & 88 & طفو الأسماك على السطح & 7 \\
\hline- & - & - & - & نسبة التغذية بالنسبة لوزن الأسماك & 8 \\
\hline 45 & 40 & 55.1 & 49 & 1 مم - 5 مم & 9 \\
\hline 21.4 & 19 & 78.7 & 70 & 6 مم - 100 مم & 10 \\
\hline 36 & 32 & 64.0 & 57 & أكبر من 100مم & 11 \\
\hline
\end{tabular}

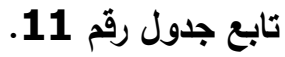

\begin{tabular}{|c|c|c|c|c|c|}
\hline 18 & 16 & 82.0 & 73 & مواعيد تجديد مياه المزرعة السمكية & 12 \\
\hline- & - & - & - & أنسب المواعيد لبدء تشغيل المزرعة السمكية & 13 \\
\hline- & - & 41.00 & 89 & شهر مارس & 14 \\
\hline 28.9 & 25 & 71.9 & 64 & شهر أغطس & 15 \\
\hline
\end{tabular}

وبناءً على هذه النتائج فإنه يجب تخطيط البرامج الإرشادية الهادفة لتزويد المزارع بالمعارف

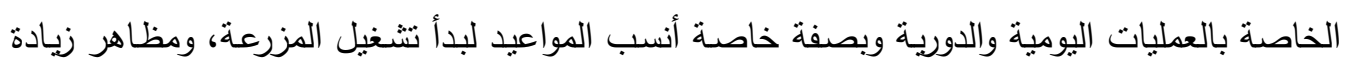

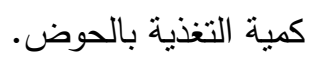
وللتعرف على العلاقة الارتباطية بين العوامل المميزة للمبحوثين والعمليات اليومية الدورية فإن النتائج بجدول (12) توضح أن قيم معامل الارتباط كالتالي:

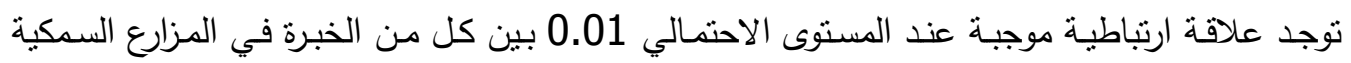

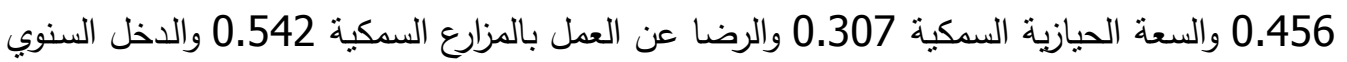
السمكي 0.425 والعمليات اليومية والدورية كما نوجد علاقة ارتباطية عند المستوى الاحتمالي 0.05

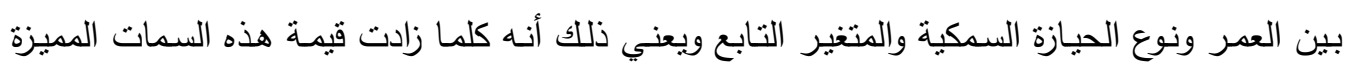
للمبحوثين فإن قيمة المعارف بالعمليات اليومية والدورية تزداد بينما لا نوجد علاقة بين باقي المتغيرات المستقلة.

جدول رقم 12. المتغيرات المرتبطة بمعارف المبحوثين في العمليات الدورية واليومية

\begin{tabular}{|c|c|c|}
\hline مستوى المعنوية & قيم معامل الارتباط البسيط & المتغيرات \\
\hline 0.05 & $* 0.225$ & 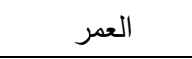 \\
\hline- & 0.013 & المستوى التعليمي \\
\hline
\end{tabular}




\begin{tabular}{|c|c|c|}
\hline 0.01 & $* * 0.456$ & الخبرة في المزارع السمكية \\
\hline 0.05 & $* 0.229$ & نوع الحبازة السمكية \\
\hline 0.01 & $* * 0.307$ & السعة الحيازية السمكية \\
\hline- & 0.147 & التعرض لوسائل الإعلام \\
\hline 0.01 & $* * 0.542$ & الرضا عن العمل بالمزارع السمكية \\
\hline- & 0.180 & المستوى الطموحي بالمزارع السمكية \\
\hline
\end{tabular}

تابع جدول رقم 12.

\begin{tabular}{|c|c|c|}
\hline- & 0.032 & الاتصال بالإرشاد السمكي \\
\hline- & 0.193 & المشاركة في الأنشطة الإرشادية \\
\hline 0.01 & $* * 0.425$ & الدخل السنوي السمكي \\
\hline & & 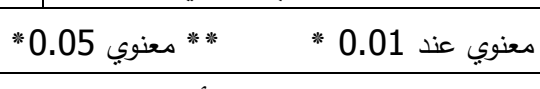 \\
\hline
\end{tabular}

وللتعرف على تأثير المتغيرات المستقلة على المتغير التابع فإن النتائج نوضـح عدم معنوية

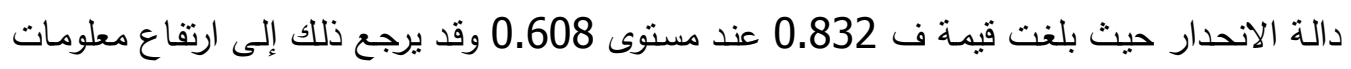

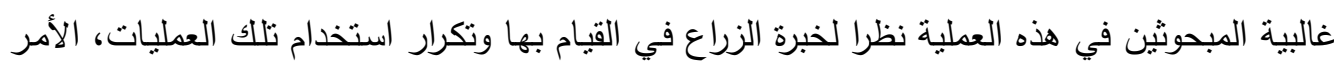

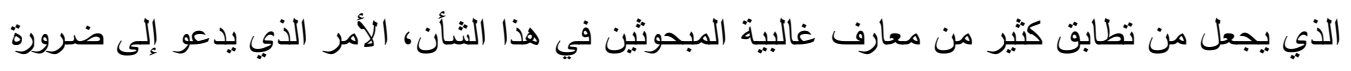

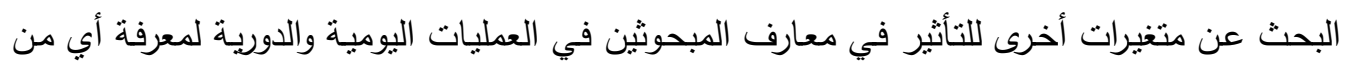
هذه المتغيرات تكون سبب التأثير الكلي وترتيب نأثثر تلاك العوامل وفقا لأهمية تأثثرها.

4- بملية التسميد والتغذية:

يتضـح من جدول (13) أن نسبة المبحوثين ذوي المستوى المنخفض 33.6\% و و المتوسط وما

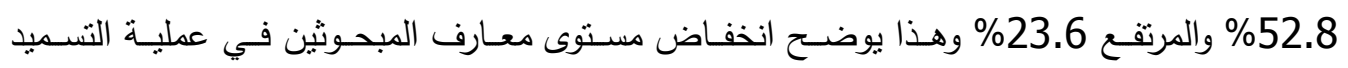
والتغذية، الأمر الذي يستلزم العمل على تزويد المبحوثين بالمعارف الخاصة بتلك العملية.

جدول رقم 13. معارف المبحوثين بعملية التسميد والتغذية

\begin{tabular}{|c|c|c|}
\hline$\%$ & العدد الع & مستوى المعارف \\
\hline 33.6 & 21 & منخفض (9 - 11 درجة) \\
\hline 52.8 & 47 & منوسط (12 - 14 درجة) \\
\hline 23.6 & 21 & مرتفع (15 - 17 درجة) \\
\hline 100 & 89 & 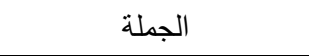 \\
\hline
\end{tabular}

بناءً على ما سبق فإنه يجب الاهتمام بإعداد مرشدين متخصصين في الاستزراع السمكي مـع

نوفير النشرات الارشادية في هذا المجال.

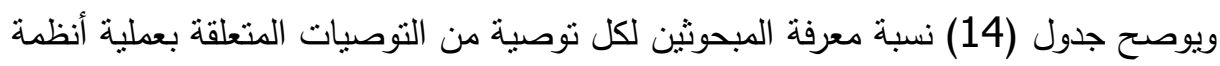

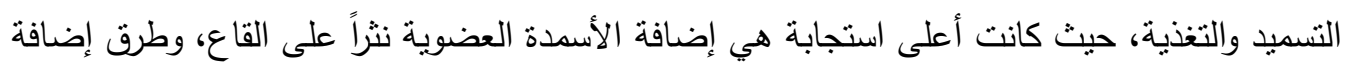

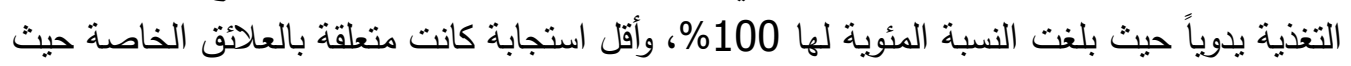
بلغت نسبتها 32.58\%، الأمر الذي يستوحب تقديم المزيد من المعارف للمبحوثين في تلك العملية. 


\begin{tabular}{|c|c|c|c|c|}
\hline$\%$ & لا لايعرف & $\%$ & يعرف ي ي ل ي & البيــان \\
\hline- & - & - & - & أنواع التشميد الذي يستخدم بالمزرعة: \\
\hline- & - & 100 & 80 & التسميد العضوي \\
\hline 24.7 & 22 & 75.5 & 67 & التنسميد الكيماوي \\
\hline- & - & - & - & ما هي طرق إضافة الأسمدة العضوية \\
\hline- & - & 100 & 89 & 500كجم نثرا على القاع \\
\hline 33.7 & 30 & 66.3 & 59 & 250 كجم/ فدان/ أسبوعين نثراً \\
\hline 14.5 & 12 & 86.5 & 77 & أنسب طرق إضافة الأسمدة الكيماوية \\
\hline 3.4 & 3 & 96.6 & 86 & ما فائدة إضافة التغذية التكميلية \\
\hline- & - & - & - & أنواع علائق الأسماك: \\
\hline 65.2 & 58 & 34.8 & 31 & 1- علائق مكملة \\
\hline 6.8 & 6 & 93.3 & 83 & 2- علائق متكاملة \\
\hline 67.4 & 60 & 32.6 & 29 & 3- علائق خاصة \\
\hline- & - & - & - & الهكونات الأساسية للعلائق المتكاملة: \\
\hline 7.9 & 7 & 92.1 & 82 & 1- البروتين \\
\hline 7.9 & 7 & 92.1 & 82 & 2- 2- الدهون \\
\hline 24.7 & 22 & 75.3 & 67 & 3- النشويات \\
\hline 41.6 & 37 & 58.4 & 52 & 4- الفيتامينات \\
\hline 39.3 & 35 & 60.7 & 54 & 5- الأملاح المعدنية \\
\hline- & - & - & - & طرق إضافة التغذية: \\
\hline- & - & 100 & 89 & 1- يدوي \\
\hline 1.1 & 1 & 98.9 & 88 & 2- ميكانيكى \\
\hline 1.4 & 3 & 96.6 & 86 & 3- عند جمع الأسماك ما هي طرق التغذية \\
\hline
\end{tabular}

وللتعرف على العلاقة الارتباطية بين العوامل المميزة للمبحوثين وعملية التسميد والتغذية فإن النتائج بجدول (15) تبين وجود علاقة ارتباطية موجبة عند المستوى الاحتمالي 0.01 بين كل من لن

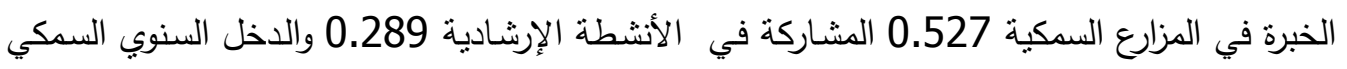
0.514 وعملية التسميد والتغذية كما نوجد علاقة ارتباطية عند المستوى الاحتمالي 0.05 والمستوى الإنية

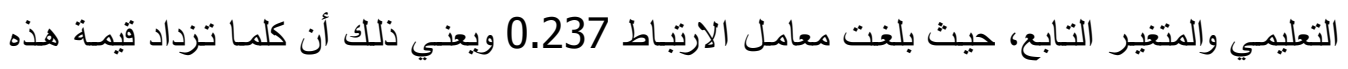

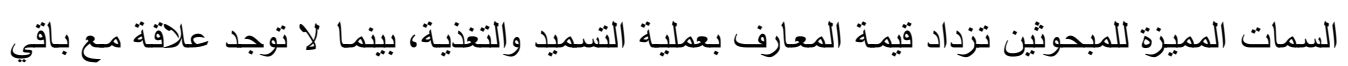

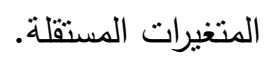

جدول رقم 15. المتغيرات المرتبطة بمعارف المبحوثين في عملية التسميد والتفنية

\begin{tabular}{|c|c|}
\hline قيم معامل الارتباط البسيط & المتغيرات \\
\hline 0.152 & 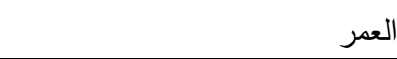 \\
\hline $0.237 *$ & المستوى التعليمي \\
\hline $0.527 * *$ & الخبرة في المزارع السمكية \\
\hline 0.196 & السعة الحيازية السمكية \\
\hline 0.048 & التعرض لوسائل الإعلام \\
\hline 0.058 & الرضـا عن العمل بالمزارع السمكية \\
\hline 0.016 & المستوى الطموحي بالمزارع السمكية \\
\hline 0.088 & الاتصال بالإرشاد السمكي \\
\hline
\end{tabular}




\begin{tabular}{|c|c|}
\hline $0.289 * *$ & المشاركة في الأنثطة الإرشادية \\
\hline $0.514 * *$ & الدخل السنوي السمكي \\
\hline & معنوي عند 0.01 \\
\hline
\end{tabular}

وللتعرف على تاثير المتغيرات المستقلة على عملية التسميد والتغذية فإن النتائج توضح عدم

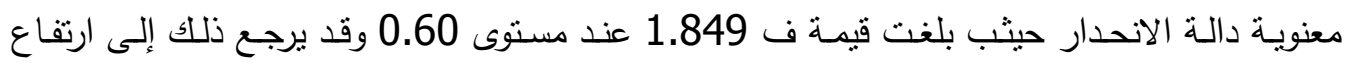
معلومات غالبية المبحوثين في هذه العملية نظراً لأهميتها الثديدة والقديمة منذ بدأ عملية الاستزراع

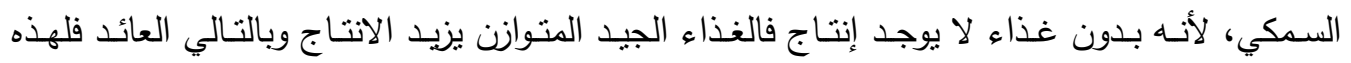

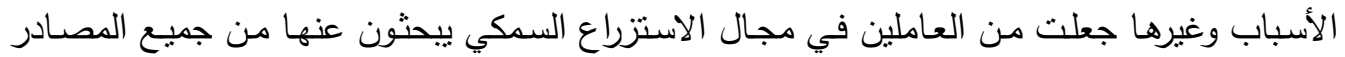
المتاحة فجعلت من ارتفاع غالبية المربين لدرجة التنابه والنطابق. 5- عملية التسويق وإنتاج الأسماك:

يتضح من جدول (16) أن نسبة المبحوثين ذوي المستوى المعرفي المنخفض بلغت 52.8\% والمتوسط 30.3\% والمرتفع 16.9وهذا يوضح معارف المبحوثين عن عملية التسويق وإنتاج الأسماك.

جدول رقم 16. معارف المبحوثين عن عملية التسويق وإنتاج الأسماك

\begin{tabular}{|c|c|c|}
\hline$\%$ & 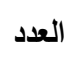 & مستوى المعارف \\
\hline 52.8 & 47 & منخفض (9 - 11 درجة) \\
\hline 30.3 & 27 & متوسط (12 -14 درجة) \\
\hline 16.9 & 15 & مرتفع (15 - 16 درجة) \\
\hline 100 & 89 & الجملة \\
\hline
\end{tabular}

يوضـح جدول (17) نسبة معـارف المبحوثين لكل توصية مـن التوصيات المتعلقـة بعمليـة

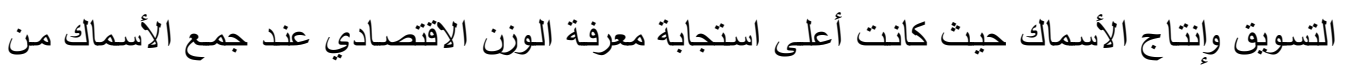

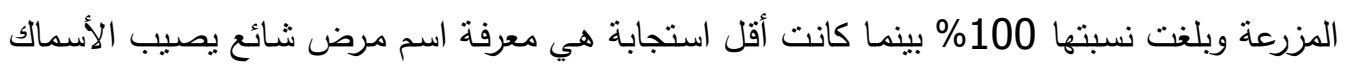
حيث بلغت نسبتها 17.97\% الأمر الذي يؤدي إلى ضرورة تزويد المبحوثين بمزيد من المعارف في

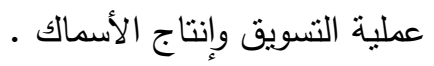

جدول رقم 17. معارف المبحوثين بعملية التسويق وإنتاج الأسماك

\begin{tabular}{|c|c|c|c|c|}
\hline$\%$ & لا يعرف & $\%$ & يعرف & البيـــان \\
\hline 23.6 & 21 & 76.4 & 68 & الددة المناسبة لدورة التربية في الاستزراع السمكي \\
\hline- & - & 100 & 89 & الوزن الاقتصادي عند جمع الأسماك \\
\hline 50.6 & 45 & 49.4 & 44 & الكثافة الهناسبة بحوض التربية \\
\hline 4.5 & 4 & 95.5 & 85 & أفضل توقيت جمع الأسماك في اليوم \\
\hline
\end{tabular}




\begin{tabular}{|c|c|c|c|c|}
\hline- & - & - & - & ما هي أفضل مواعيد تسويق الأسماك في العام؟ \\
\hline 29.2 & 26 & 70.8 & 63 & 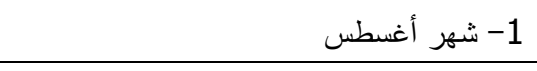 \\
\hline 3.4 & 3 & 96.6 & 86 & 2- شهر يناير \\
\hline
\end{tabular}

تابع رقم جدول 17.

\begin{tabular}{|c|c|c|c|c|}
\hline 7.9 & 7 & 92.1 & 82 & 3- شهر مايو \\
\hline 60.0 & 53 & 40.0 & 36 & عدد دورات الإنتاج المُتلى في العام \\
\hline- & - & - & - & اسم ثلاثة أمراض شائعة تصيب الأسماك \\
\hline 82.3 & 73 & 18.0 & 16 & 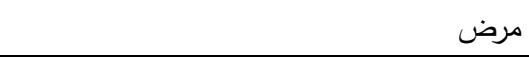 \\
\hline 68.5 & 61 & 31.5 & 28 & مرضين \\
\hline 48.3 & 75 & 15.7 & 14 & ثلاثة أمراض \\
\hline 50.6 & 45 & 49.4 & 44 & كيفية الوقاية من الأمراض التي تصيب الأسماك \\
\hline- & - & - & - & في حالة وجود أي من الأمراض ماذا تفعل \\
\hline 68.4 & 61 & 31.6 & 28 & طريقة علاج واحدة \\
\hline 93.3 & 83 & 6.7 & 6 & طريقتين علاج \\
\hline 47.2 & 42 & 52.8 & 47 & ت ثلاث طرق علاج \\
\hline
\end{tabular}

وللتعرف على العلاقة الارتباطية بين العوامل المميزة للمبحوثين وعملية التسويق والانتاج فإن النتائج بجدول (18 ) تشير إلى وجود علاقة ارتباطية موجبة عند المستوى الاحتمالي 0.01 بين كل

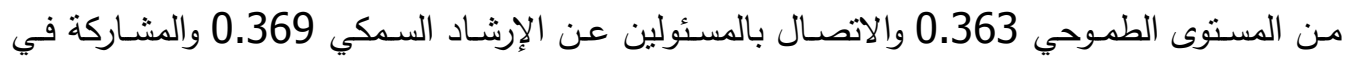

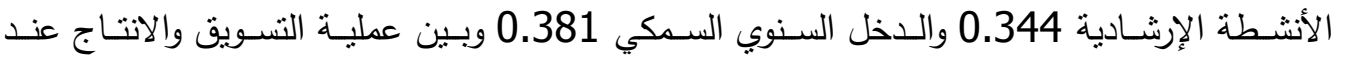
المستوى الاحتمالي 0.05 و التعرض لوسائل الإعلام 0.215 جدول رقم 18. المتغيرات المرتبط بمعارف المبحوثين في عملية التسويق وإنتاج الأسماك

\begin{tabular}{|c|c|}
\hline قيم معامل الارتباط البسيط & المتغيرات \\
\hline 0.144 & 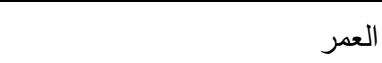 \\
\hline 0.084 & المستوى التعليمي \\
\hline 0.012 & الخبرة في المزارع السمكية \\
\hline 0.015 & نوع الحيازة السمكية \\
\hline $0.215 *$ & التعرض لوسائل الإعلام \\
\hline
\end{tabular}

تابع جدول رقم 18.

\begin{tabular}{|c|c|}
\hline 0.194 & الرضا عن العمل بالمزارع السمكية \\
\hline $0.363 * *$ & المستوى الطموحي بالمزارع السمكية \\
\hline $0.369 * *$ & الاتصال بالإرشاد السمكي \\
\hline $0.344 * *$ & المشاركة في الإنشطة الإرشادية \\
\hline $0.381 * *$ & 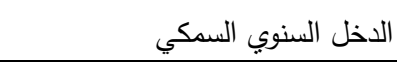 \\
\hline \multicolumn{2}{|c|}{ 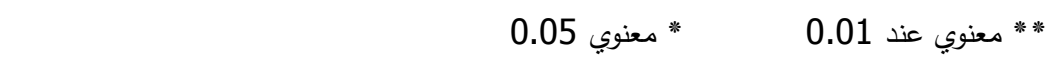 } \\
\hline
\end{tabular}


جدول رقم 19. معاملات الانحدار بين المتغيرات المستقلة ومعارف المبحوثين في عملية التسويق

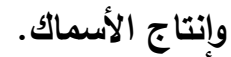

\begin{tabular}{|c|c|c|c|}
\hline مستوى المعنوية & 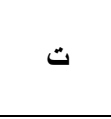 & معامل الاندار الجزئي & المتغيرات \\
\hline غير معنوي & 0.258 & 0.028 & 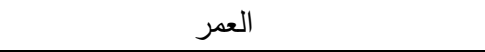 \\
\hline 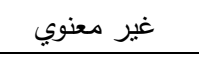 & 0.851 & 0.121 & المستوى التعليمي \\
\hline 0.05 & 3.149 & 0.380 & الخبرة في المزارع السمكية \\
\hline 0.01 & 2.917 & 0.805 & نوع الحيازة السمكية \\
\hline غير معنوي & 0.298 & 0.027 & السعة الحبازية السمكية \\
\hline غير معنوي & 0.067 & 0.012 & التعرض لوسائل الإعلام \\
\hline غير معنوي & 1.412 & 0.191 & الرضا عن العمل بالمزارع السمكية \\
\hline 0.01 & 5.047 & 0.587 & المستوى الطموحي \\
\hline 0.05 & 2.607 & $0.558 * *$ & الاتصال بالإرشاد السمكي \\
\hline غير معنوي & 1.919 & 0.218 & المشاركة في الأنشطة الإششادية \\
\hline غير معنوي & 0.014 & 0.002 & الدخل السنوي السمكي الـ \\
\hline \multicolumn{4}{|c|}{ ف = 9.573 المعنوية 0.01 ر $0.578^{2}$} \\
\hline
\end{tabular}

وللتعرف على تأثثر المتغيرات المستقلة على المتغير التابع فإن النتائج بجدول (19) تشير

إلى معنوية دالة الانحدار حيث بلغت قيمة ف 9.573 وهي قيمة معنوية عند مستوى0.1 بينما بلغ قيمة معامل الانحدار المتعدد 0.578 ويعتبر ذلك أن أربعة متغيرات (السمات المميزة للمبحوثين) ذات تأثثير واضح على أنظمة التربية والاستزراع السمكي بنسبة 75.8\% وباقي التأثير يرجع إلى متغيرات أخرى، وقد أوضحت النتائج أن المتغيرات المؤثرة هي: نوع الحيازة السمكية (805,) والمستوى الطموحي (587، ) والاتصـال بالإرشاد السمكي 558، عند السئ 0.01 بينما الخبرة في المزارع السمكية 0.380 عند 0.05 وهذه النتائج تبين أهمية المعارف المتعلقة بالتسويق والإنتاج والتي يستلزم (التزود بها للحصول على فئل إنتاج وفي ودخل مرتقع من تسويق الأسماك)

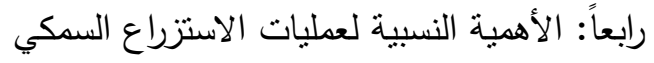
أن عملية الاستزراع السمكي تتكون من خمسـة عمليات فرعيـة مكملة كل منها للآخر ولـه أهيته على حدى وعلى مستوى عمليات الاستزراع السمكي وهي:

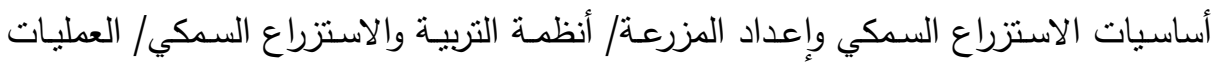
اليومية والدورية/ عملية التسميد والتغذية/ عملية النسويق وإنتاج الأسماك. جدول (20). جدول رقم 20. الأهمية النسبية للأحتياج المعرفي للمبحوثين في عمليات الاستزراع السمكي مرتبة تصاعديا

\begin{tabular}{|c|c|c|}
\hline الأهمية النسبية & \%الاحتياج المعرفي & العمليات \\
\hline الأول & 57.29 & العمليات اليومية والدورية \\
\hline
\end{tabular}




\begin{tabular}{|c|c|c|}
\hline 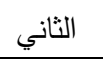 & 76.40 & عملية التسميد والتغذية \\
\hline 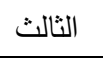 & 83.13 & عملية النسويق والإنتاج \\
\hline 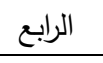 & 86.51 & أنظمة التربية والاستزراع السمكي \\
\hline 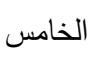 & 91.00 & ساسيات الاستزراع السمكي وإعداد المزرعة \\
\hline
\end{tabular}

وقد تم ترتيب هذه العمليات من حيث الأهية النسبية وفقا للاحتياج المعرفي فاحتل المركز

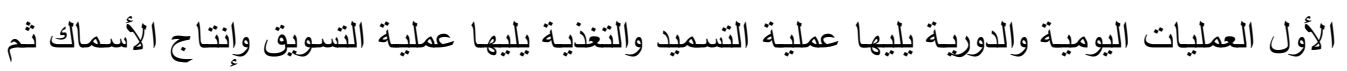

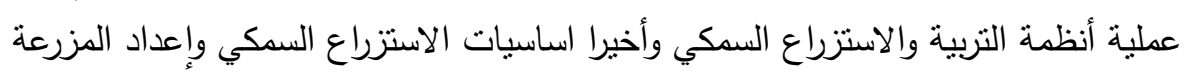

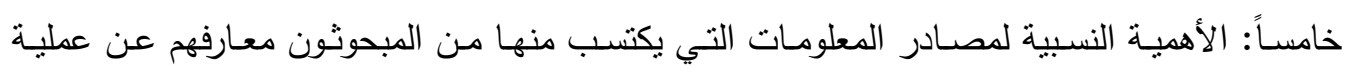

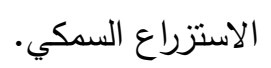
أظهرت النتائج الموضحة بجدول (21) الترتيب التتازلي للمصادر المعرفية التي يرى الزراع

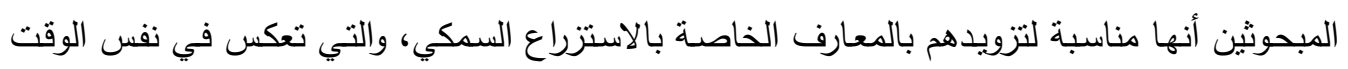

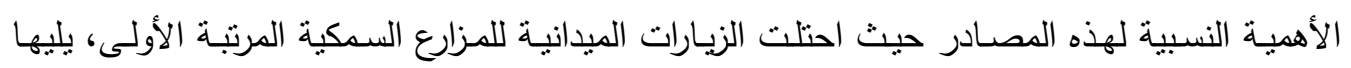

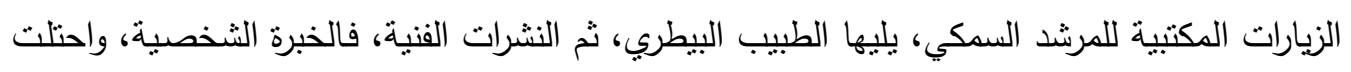

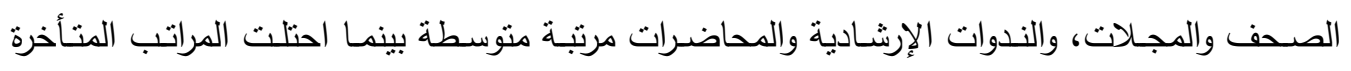

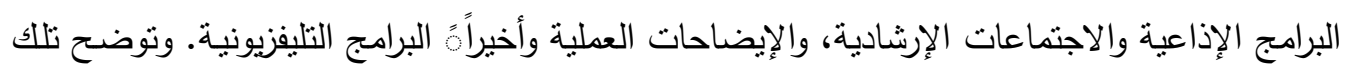

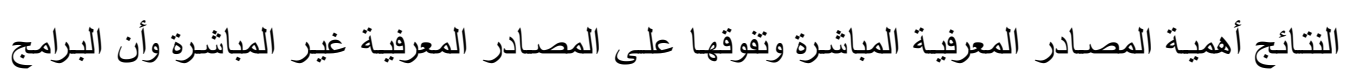

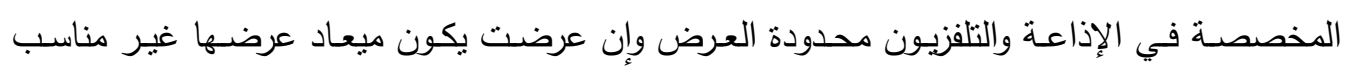
للمبحوثين.

جدول رقم 21. الأهميـة النسبية للمصـادر التي يكتسب منها للمبحوثـون معارفهم عن عمليـات الاستزراع السمكي

\begin{tabular}{|c|c|c|}
\hline الترتيب & 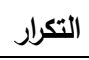 & المصدر \\
\hline الأول & 195 & الزيارات الميدانية للمزارع السمكية \\
\hline الثاني & 188 & الزيارات المكتبية للمرشد السمكي \\
\hline الثالث & 143 & الطبيب البيطري \\
\hline 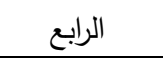 & 81 & الأهل والأقارب والجيران \\
\hline الخامس & 70 & النشرات الفنية \\
\hline 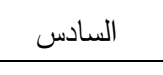 & 53 & الخبرة الثخصية \\
\hline 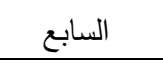 & 29 & الصحف والمجلات \\
\hline 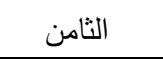 & 24 & الندوات الإرشادية \\
\hline 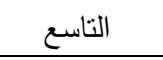 & 15 & المحاضرات \\
\hline العاشر & 11 & البرامج الإذاعية \\
\hline الحادي عشر & 8 & الاجتماعات الإرشادية \\
\hline الثاني عشر & 8 & الإيضاحات العملية بالممارسة \\
\hline الثالث عشر & 7 & البرامج التلبفزيونية \\
\hline
\end{tabular}


سادساً: أهم المشاكل التي تواجه المبحوثين في عمليات الاستزراع السمكي.

يوضح جدول (22) المشاكل التي تواجه المبحوثين حيث تبين أن 93.25\% من المبحوثين

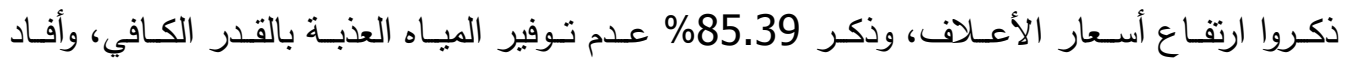

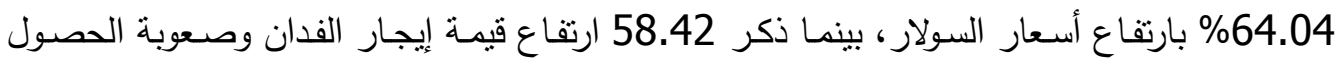

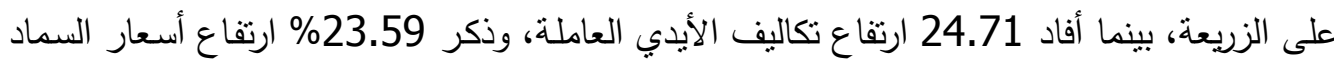

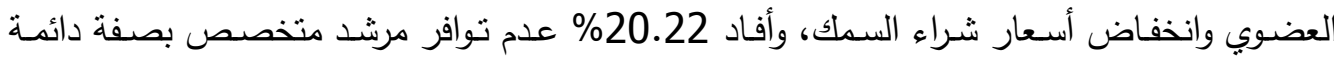

بالمنطقة بينما ذكر 14.60 قلة الطرق والبرامج الإرشادية المستخدمة وكثرة الأمراض وانتشارها.

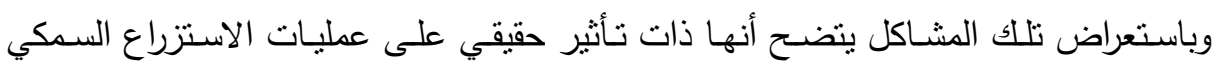

ومدى التوسع فيها وانتشارها والعناية بها وبالتالي الزيادة الإنتاجية والدخل وتحسين مستوى المعيشة.

جدول رقم 22. المشاكل التي تواجه المبحوثين مرتبة تنازلياً وفقاً لأهميتها النسبية

\begin{tabular}{|c|c|c|c|}
\hline$\%$ & 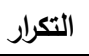 & 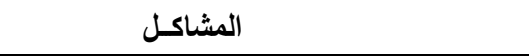 & 5 \\
\hline 93.25 & 83 & ارتفاع أسعار الأعلاف & 1 \\
\hline 85.39 & 76 & عدم توفير العياه العذبة بالقدر الكافي & 2 \\
\hline 64.04 & 57 & ارتفاع أسعار السولار & 3 \\
\hline 58.42 & 52 & ارتفاع قيمة إيجار الفدان & 4 \\
\hline 58.42 & 52 & صعوبة الحصول على الزريعة & 5 \\
\hline 24.71 & 22 & ارتفاع تكاليف الأيدي العاملة & 6 \\
\hline 23.59 & 21 & ارتفاع أسعار السبلة (السماد العضوي) & 7 \\
\hline 23.59 & 21 & انخفاض أسعار السمك عند التسويق & 8 \\
\hline 20.22 & 18 & عدم نوافر مرشد منخفض بصفة دائمة بالمنطقة & 9 \\
\hline 14.60 & 13 & قلة الطرق والبرامج الإرشادية المستخدمة & 10 \\
\hline 14.6 & 13 & كثرة الأمراض وانتثارها & 11 \\
\hline
\end{tabular}

مقترحات المبحوثين للتظلب على المشاكل التي تواجههم

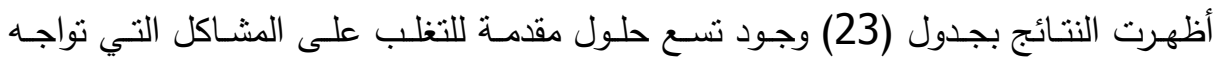

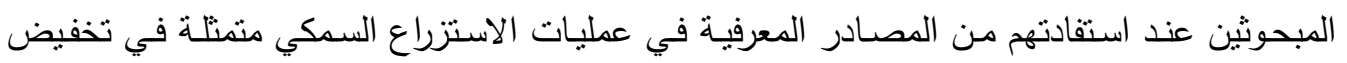

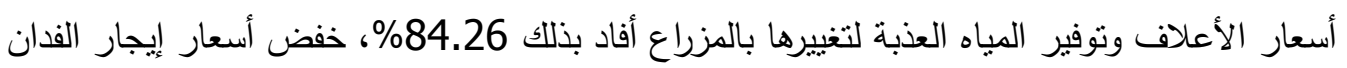

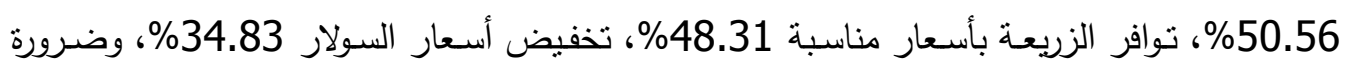
تواجد مرشد متخصص بالمنطقة 20.22\%، وخفض تكاليف العمالة 16.85\%، والأهتمام باستخدام 
مختلف الطرق والبرامج الإرشـادية 14.6\%، وضـرورة توافر سبل العـلاج والخدمات البيطري بأسعار مناسبة 10.11\% وباستعراض الحلول المقترحة السابقة تبين أنها جميعا جديرة بالاهتمام من قبل المسئولين عن تتمية الثروة السمكية للتغلب على المشاكل التي تواجه المبحوثين. جدول رقم 23. العلـول المقترحة للمشـاكل التي تواجه المبحوثين في عمليـة الاستزراع السـكي مرتبة تنازليا وفقا لأهميتها النسبية

\begin{tabular}{|c|c|c|c|}
\hline$\%$ & التكرار & العلـول & م \\
\hline 84.26 & 75 & تخفيض أسعار الأعلاف & 1 \\
\hline 84.26 & 75 & توفير المياه العذبة للمزارع & 2 \\
\hline 50.56 & 45 & خفض أسعار إيجار الفدان & 3 \\
\hline 48.31 & 43 & توافر الزريعة بأسعار مناسبة & 4 \\
\hline 34.83 & 31 & تخفيض أسعار السولار & 5 \\
\hline 20.22 & 18 & تواجد مرشد متخصص بالمنطقة & 6 \\
\hline 16.85 & 15 & خفض تكاليف الأيدي العاملة & 7 \\
\hline 14.60 & 13 & الاهنمام باستخدام الطرق والبرامج الإرشادية & 8 \\
\hline 10.11 & 9 & ضرورة توافر سبل العلاج والتحصينات والخدمات البيطرية بأسعار مناسبة & 9 \\
\hline
\end{tabular}

التوصيات

1- الحاجة إلى إجراء مزيد من البحوث في مجال تطوير عملية الاستزراع السمكي وتوظيف نتائج الدراسات في واقع الممارسة الميدانية والتطبيقية. 2- الحاجة إلى بلورة نظام لنوثيق إجراءات تشكيل تتظيم تعاوني يضم العاملين في عملية الاستزراع

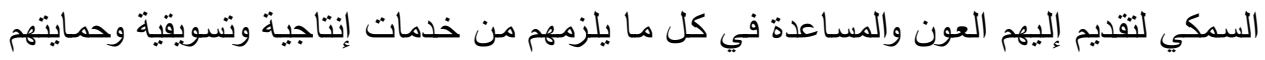
من التعرض للأخطار المفاجئة. 3- العمل على التتسيق بين كل من التظيم التعاوني للعاملين، وهيئة الثروة السمكية وهيئة الخدمات

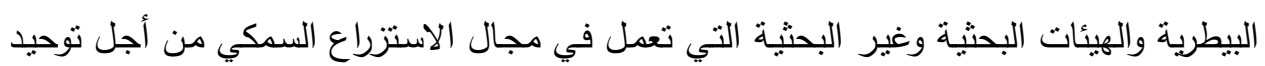
جهودهم لخدمة العاملين في هذا المجال.

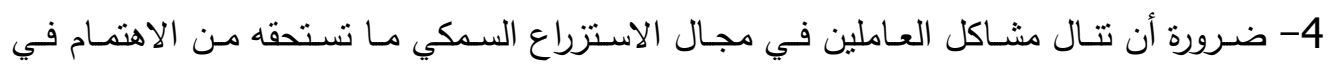
الانشطة والبرامج الإرشادية في مجال الاستزراع السمكي والعمل على التخلص من المشاكل بما لـال

$$
\text { يرغب فيه الزراع. }
$$

5- تكثيف الجهود الإرشادية والإعلامية لتزويد العاملين بمختلف المعارف وإكسابهم مهارات تساعدهم على زيادة الإنتاج وتذليل العقبات التي تواجهـهم. 6- ضرورة العمل على تواجد عدد كافي من المرشدين في مجال الاستزراع السمكي بجانب العاملين في مجالات الاستزراع السمكي بصفة دائمة. 
7- نوحيد الجهود بين الإرشاد السمكي والإرشاد الزراعي ممثلا في قسم الإنتاج الحيواني من أجل

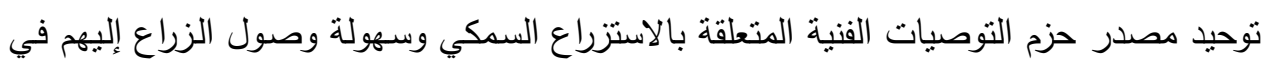

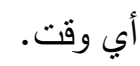

1) إبراهيم، عصام محمد (دكتور ) - المنظومة البيئية للأسماك، مجلة ربع سنوية، العدد السادس، أكتوبر 2008.

2) الجنجيهي، هدى محمد (دكتور )- دراسة تحليلية لنظام واستقبال المعلومات الإرشادية المحمولة

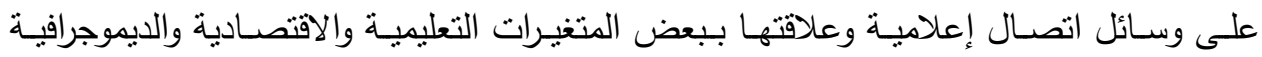

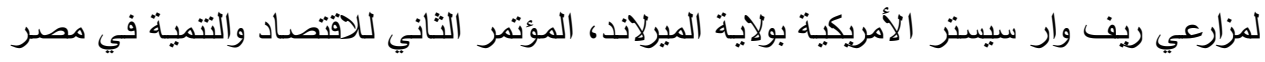

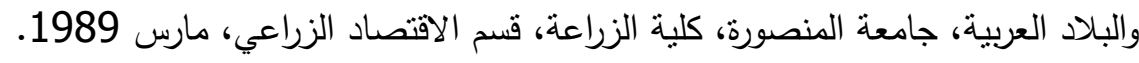

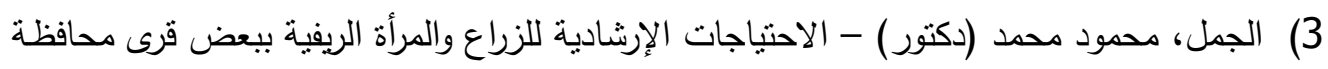

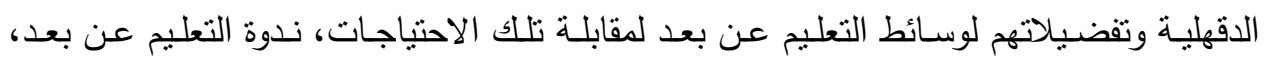

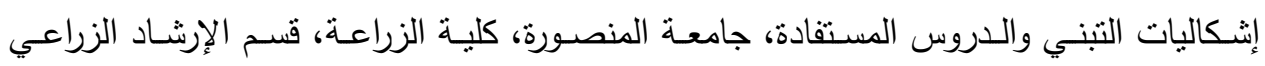

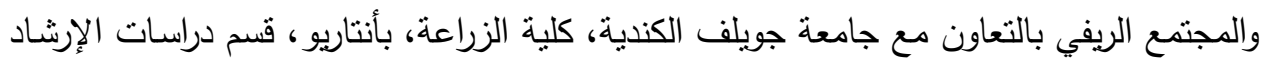

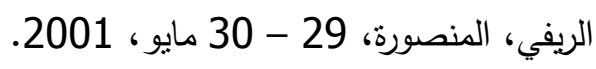

4) الدحار , علاء عبد الكريم (دكتور) - الاستزراع المائي ماله وما عليه، الندائه الندوة العلمية الثانية لتتمية

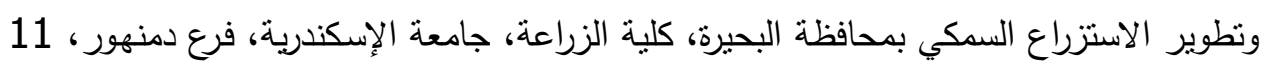

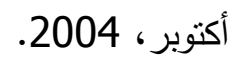


5) الطنوبي، محمد محمد عمر (دكتور ) - المرجع في الإرشـاد الزراعي، دار المطبوعات الجديدة الإسكندرية، 1973.

6) العـادلي، أحمـد السـيد (دكتور) - أساسـيات علـم الإرشــاد الزراعي، دار المطبوعـات الجديدة، الإسكندرية، 1973.

7) الهيئة العامة للثروة السمكية - الإحصائيات السنوية، 2006.

8) بدارن، شكري محمد، محمود مصطفى معوض، نرجس حلمي بباوي (دكاترة) - الدور الإرشادي

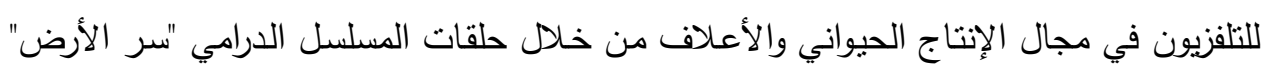

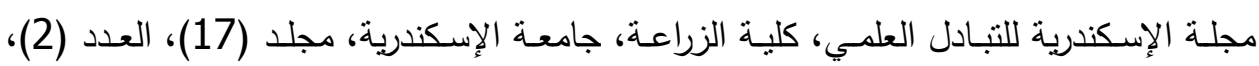
.1996

9) ناج، عبد الرازق (دكتور) - جودة المياه وعلاقتها بالاستزراع السمكي، الندوة العلمية الثانية لتتمية

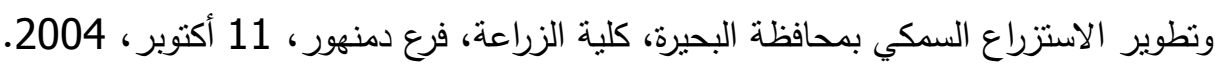

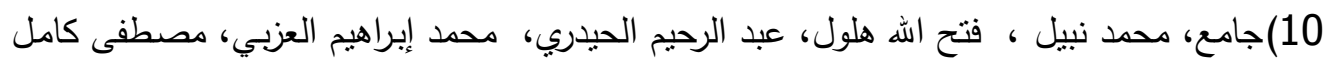

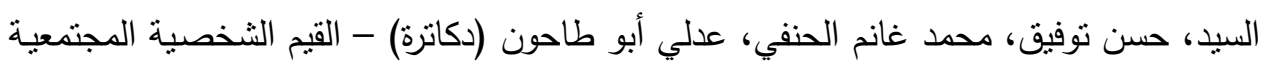

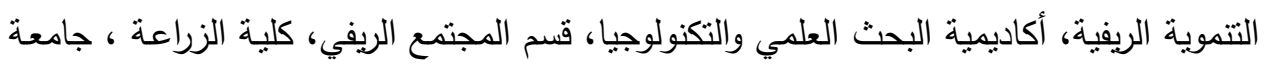
الإسكندرية، أغسطس، 1989.

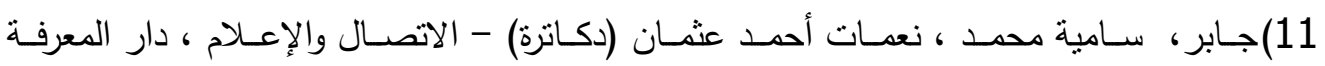

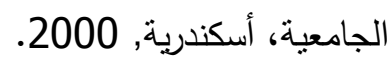

12)حافظ, مصطفى كمال (دكتور ) - السلوك المعرفي التتفيذي للزراع الخريجين في مجال استخدام

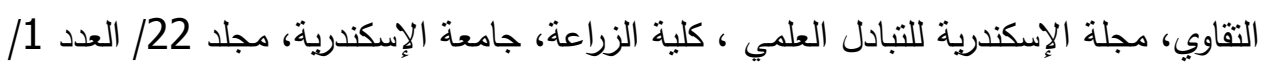
يناير، مارس 2001. 13)حافظ، مصطفى كمال (دكتور)- دراسة بعض المتغيرات المؤثرة على استخدام الزراع لمصادر

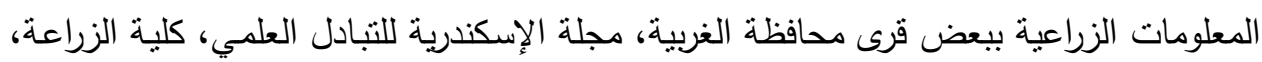

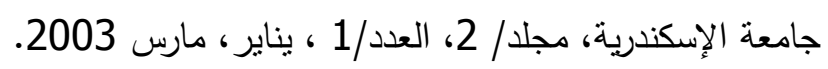

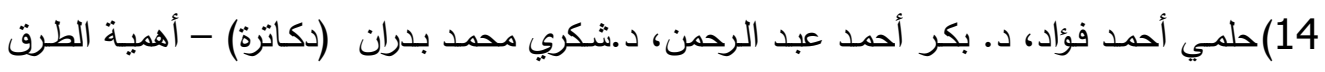

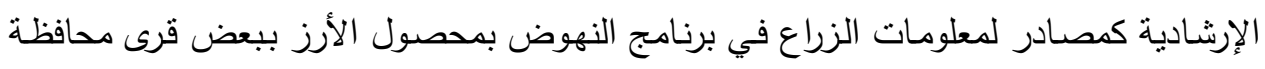

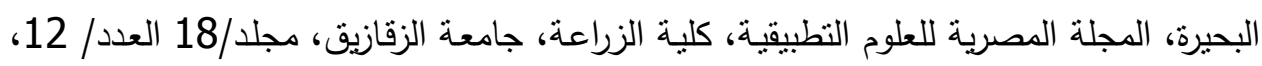
ديسمبر 2003.

15) السيد، أحمد فؤاد ، جمال محمد محارم، زينب علي عبدة (دكاترة) - الأهمية النسبية لمصادر معلومات المربين في مجال إنتاج الأغنام ببعض قرى مركز برج العرب بمحافظة الإسكندرية،

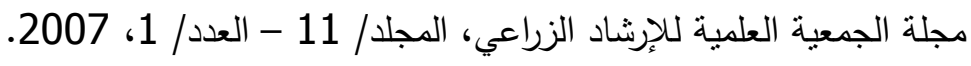

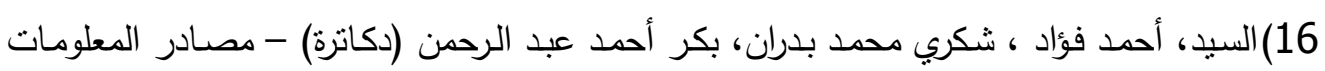

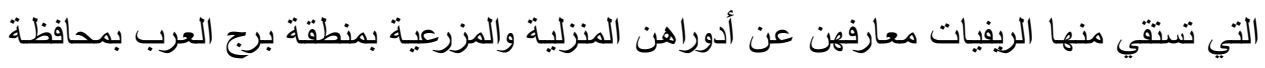

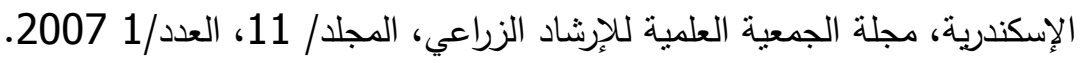


17) رمضـان، أحمد، محمد القصاص (دكاترة) - دراسـة معارف وممارسات زراع بطاطس التصدير لعمليات التقليع والفرز والتعبئة في بعض القرى المتخصصة بجمهورية مصر العربية، نشرة بحثية رقم/ 265، معهد بحوث الإرشاد الزراعي والتتمية الريفية، مركز البحوث الزراعية - 2001.

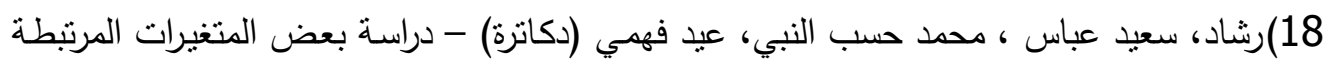

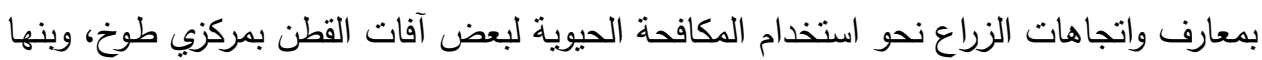

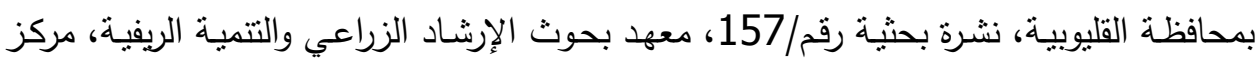
البحوث الزراعية، 1997.

19)سرور، عبد اللطيف عبد العاطي (دكتور)- تبني الممارسات والتقنيات المزرعيـة بين الزراع

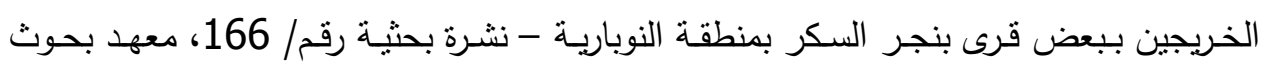
الإرشاد الزراعي والتتمية الريفية، مركز البحوث الزراعية، 1996.

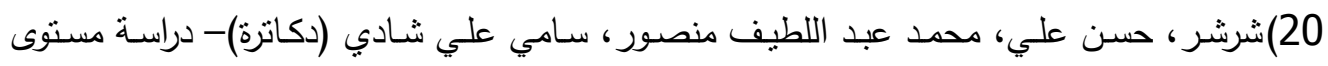

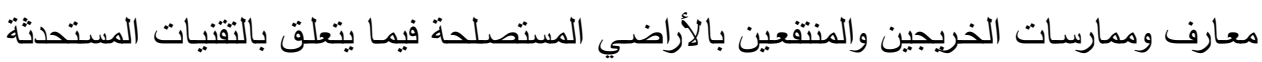

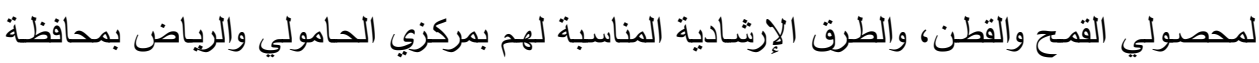

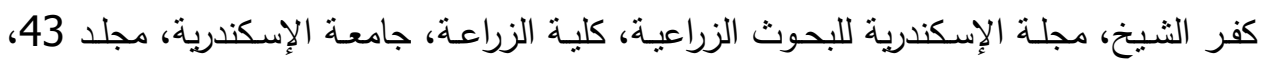
ديسمبر ، 1998.

21)صالح، أحمد محد (دكتور)، التحليل العام لاستجابة الزراع لوسائل الاتصال الإرشادي في إحدى

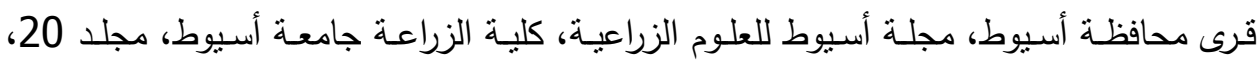

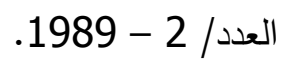

22) صالح، صبري، محمد محمد عمر الطنوبي، سـير محمد عزمي (دكانزة) - الإرشـاد الزراعي أساسياته وتطبيقاته، مركز الإسكندرية للكتاب،

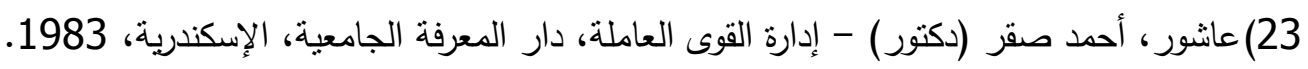

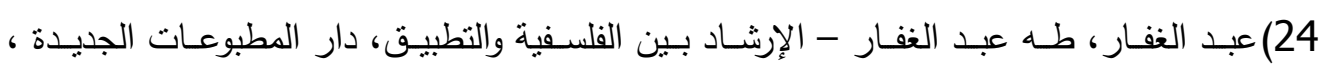

$$
\text { الإسكندرية/ } 1976 .
$$

25) عصمت، محمد حسن، حمدي السيد أنور ، أحمد محمود الكتاتتي (دكاترة) - استخدام تكنولوجيا أنتعة الليزر في تسوية الأراضي الزراعية بمحافظة سوهاج، مؤتمر استراتيجية إنتاج زراعي آمن

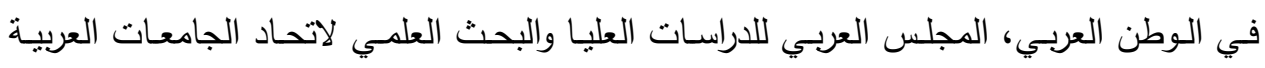

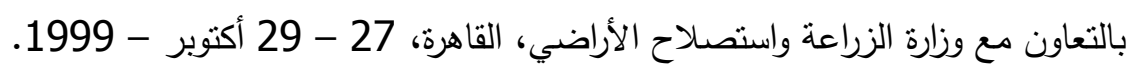

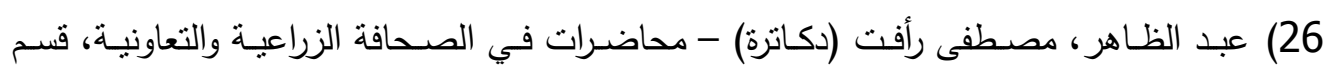
الاقتصاد الزراعي، كلية الزراعة - جامعة الإسكندرية -غير مبين السنة.

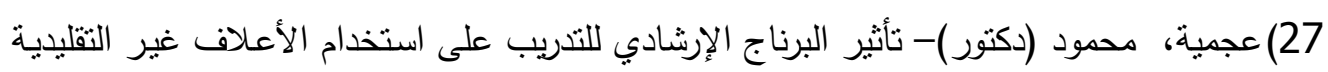

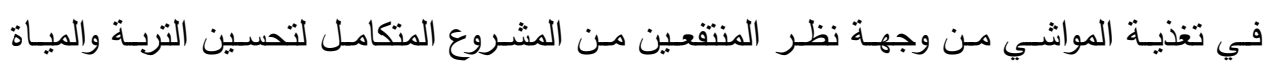
بالدقهلية، نشرة رقم 136، معهد بحوث الإرشاد الزراعي والتتمية الريفية، مركز البحوث الزراعية 
28) عمر ، أحمد محمد (دكتور ) - الإششـاد الزراعي المعاصـر، مصر للخدمات التعليمية، القاهرة، 1992

29)فريد، محمد أحمد، أسـامة أبو المكارم، عاطف هـلال (دكاترة) - نحو بناء مقياس لاتجاهـات

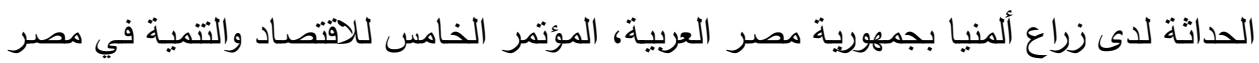
والبلاد العربية، جامعة المنصورة، أبريل - 1996.

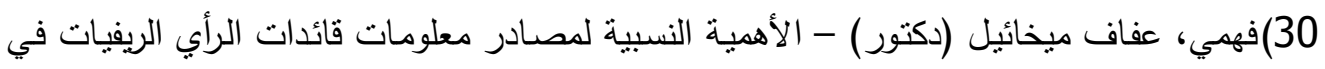

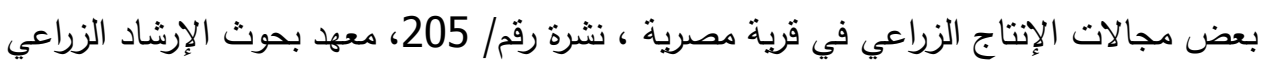
والتتمية الريفية، مركز البحوث الزراعية ، 1998.

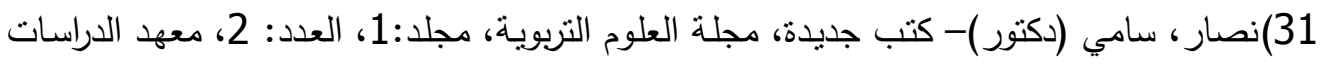
التربوية، جامعة القاهرة ، سبتمبر 1994.

32) هلول فتح الله (دكتور) محمد الغنيمي - الآثار الاجتماعية والاقتصادية للتصنيع على المناطق

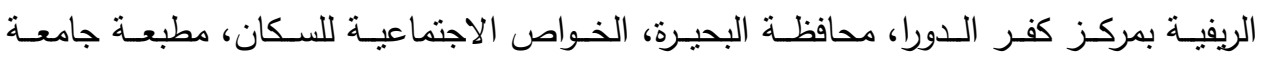
الإسكندرية - نشرة رقم/3، الإسكندرية - 1996.

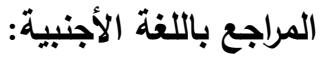

1- Tripothi S, and Tripathi, J, N. comparative effectiveness of extension teaching methods, the Allabad farmer, volume No.4 Allabad agricultural Institante, India, 1971.

2- Volan S, audio Visual aids - communication Guide, Extension Development unit, ministry of agriculture, London, 1979. 


\title{
FISH FARMERS KNOWLEDGE AND INFORMATION SOURCES RELATED TO FISH FARMING IN SIDI - SALEM AND EL RIAD DISTRICTS, KAFR EL - SHIKH GOVERNORATE
}

\author{
A. F. HELMY, H. A. SHARSAR, S. A. EL - GHAMRINI \\ Professor, agricultural Extension and Rural Development Research Institute, \\ Agricultural Research Center.
}

(Manuscript received 23 February 2011)

\begin{abstract}
The main objective of the research was to determine fish farmers knowledge related to fish farming and their information resources in this regard.

Some other objectives were affiliated with the previously mentioned main objective. Those objectives were;

1- to identify fish farmers' knowledge acquired from their information sources related to fish farming.

2- to determine relationship between the personal characteristics of the farmers and their knowledge concerning fish farming.

3- to determine importance of fish farming processes.

4- to determine importance of information sources from which fish farmers acquired their knowledge in relation with fish farming.

5- to determine different problems that hinder the farmers for benefiting from information sources and their suggested solutions to those problems.

A pretsted questionnaire and interpersonal interview were used for collecting the study data. A simple random sample encompassed 89 fish farmers Of Sidi - Salem and ElRiad districts, Kafrel - Shikh Governorate was used. Alpha coefficient, percentage, simple correlation coefficient, multiple regression were used for analyzing the obtained study data.
\end{abstract}

\section{The main study findings were as the following:}

First: there was a positive significant relationship between fish farmers' knowledge and each of the independent variables: educational level, experience period in fish farming, fish farming ownership, exposure to media channel, self - satisfaction due to work in fish farming, ambition level to work in fish farming communication with fish farming extension, and annual income.

Second: Experience period in fish farming and fish farming ownership combined together explained about $45.9 \%$ of the variance in the dependent variable. 
Third: the main sources of: farm visits, office visits, and veterinary doctors were on top of the study participants' information knowledge, followed by experience period in fish farming, newspapers, magazines, extension lectures, radio programs, and TV programs.

Fourthly: the major problems facing respondents in their using knowledge sources are: High of price concentrated food, shortage of water the farms, high of price gas oil, high of the cost price wages, lack of extension agents, reduce of the price sale, fish for trades. Their suggestions to solve such problems are: reduce of price concentrated food, provide of water the farms, reduce of price gas oil, reduce of the cost price wages, increase of extension agents, high of the price sale fish for trades. 